\title{
Domestic Filth Flies in New Haven, Connecticut: A Case Study on the Effects of Urbanization and Climate Change by Comparing Fly Populations after 78 Years
}

\author{
Julie Pinto ${ }^{1, *}$, Paola A. Magni ${ }^{1,2}$, R. Christopher $\mathrm{O}^{\prime}$ Brien $^{3}$ and Ian R. Dadour ${ }^{4}$ \\ 1 Discipline of Medical, Molecular \& Forensic Sciences, Murdoch University, 90 South Street, \\ Murdoch, WA 6150, Australia; P.Magni@murdoch.edu.au \\ 2 Murdoch University Singapore, King's Centre, 390 Havelock Road, Singapore 169662, Singapore \\ 3 Criminal Justice and Forensic Sciences Department, Henry C. Lee College of Criminal Justice and Forensic \\ Sciences, University of New Haven, West Haven, CT 06516, USA; RcOBrien@newhaven.edu \\ 4 Source Certain International Pty Ltd., P.O. Box 1570, Wangara DC, WA 6947, Australia; \\ ian.dadour@sourcecertain.com \\ * Correspondence: 33473116@student.murdoch.edu.au
}

check for

updates

Citation: Pinto, J.; Magni, P.A.; O'Brien, R.C.; Dadour, I.R. Domestic Filth Flies in New Haven,

Connecticut: A Case Study on the Effects of Urbanization and Climate Change by Comparing Fly Populations after 78 Years. Insects 2021, 12, 972. https://doi.org/ $10.3390 /$ insects 12110972

Academic Editor: Tibor Magura

Received: 13 September 2021

Accepted: 20 October 2021

Published: 27 October 2021

Publisher's Note: MDPI stays neutral with regard to jurisdictional claims in published maps and institutional affiliations.

Copyright: (c) 2021 by the authors. Licensee MDPI, Basel, Switzerland. This article is an open access article distributed under the terms and conditions of the Creative Commons Attribution (CC BY) license (https:/ / creativecommons.org/licenses/by/ $4.0 /)$.
Simple Summary: Domestic filth fly population data were collected in the summers of 1942-1944 in the urban city of New Haven, Connecticut, during a polio epidemic. The current survey was completed 78 years later by setting out a weekly trap in the same region during June-September over a two-year period. Results indicate that the fly population has changed in the city, with 16 fewer species trapped overall, and there have been changes in the fly species trapped. Some species have increased in abundance, notably Lucilia coeruleiviridis, while numbers of the common Lucilia sericata have decreased, and Lucilia illustris was absent. Changes in land cover and climate were also assessed to show that the trap site has experienced significant habitat change, together with an increase in the average temperature and rainfall. Fly numbers were significantly affected by temperature and rainfall in both the 1940s and the current survey. The results of this study suggest the prolonged period of urbanization of the region is influencing the domestic filth fly population.

Abstract: Changes in common and widespread insect populations such as the domestic filth fly in urban cities are useful and relevant bioindicators for overall changes in the insect biomass. The current study surveyed necrophagous flies by placing a weekly trap from June-September over a two-year period in the city of New Haven, Connecticut, to compare data on fly abundance and diversity with data collected 78 years earlier. Climate and land cover changes were also assessed in combination with the fly population for each period. The survey results suggest the domestic filth fly population is now less diverse with decreased species richness and changes in the relative abundance of species. In both surveys, $95-96 \%$ of the population was composed of only three species. The current survey data indicate the numerical dominance of Lucilia sericata has decreased, the abundance of several species, notably Lucilia coeruleiviridis, has increased, and Lucilia illustris is absent. Species that showed a significant interaction with temperature in the 1940s survey have now increased in abundance, with several of the trapped species continuing to show an interaction with temperature and rainfall. Analysis of the land cover and climate data characterizes the trap site as a region exposed to a prolonged period of industrialization and urbanization, with only $7 \%$ of the land cover remaining undeveloped and over 50\% impervious, coupled with an increase in temperature and rainfall. This study serves as a model for changes in domestic filth fly populations and other insects in similarly highly urbanized established cities.

Keywords: Diptera; Calliphoridae; abundance; landscape ecology; urbanization 


\section{Introduction}

The poliomyelitis epidemic in the United States prompted the study of local fly populations in New Haven, Connecticut, in the early 1940s [1,2]. Over three successive years, 1942-1944, flies were trapped weekly from May to October in New Haven after reports of poliovirus isolation from several fly genera and species [3-5]. The aim was to obtain information about the fly population and to find possible seasonal correlations with the total population, individual species, and the polio epidemic. Fly traps were placed near the Yale New Haven Hospital $\left(41^{\circ} 18^{\prime} 12.2^{\prime \prime}\right.$ N $\left.72^{\circ} 56^{\prime} 08.1^{\prime \prime} \mathrm{W}\right)$ located near the "Hill" region, which was the original focus of the 1943 poliomyelitis epidemic in the city. Flies are responsible (not solely) for the transmission of a variety of viral, bacterial, and protozoal pathogens of public health importance [6-10] with domestic families of filth flies including flesh flies (Diptera: Sarcophagidae), house flies (Diptera: Muscidae), and blow flies (Diptera: Calliphoridae) acting as vectors of human disease. Transmission is facilitated by their synanthropic feeding and reproductive habits and their ability to mechanically transmit disease by the translocation of pathogens through defecation, regurgitation, and on their exoskeleton [6,11].

The historical collection of local population data offers the rare opportunity to compare the abundance and composition of domestic filth fly species of a specific locality to present day samples. In addition to their medical significance, flies are also forensically and ecologically important. The forensic application of blow flies to death investigations is now also recognized and has been extensively used since the 1980s [12,13]. Blow flies are the primary colonizers of decomposing bodies, making their species-specific developmental data together with the local temperature of value when estimating the minimum postmortem interval $[13,14]$.

The ecological importance of blow flies as necrophagous consumers, decomposers, parasites, and as pollinators $[15,16]$ is fundamental to the ecosystem. Blow flies have adapted to live in highly modified environments that are often inhospitable to other insects [17], resulting in their common and wide distribution. In the past, the abundance of common and widespread species has been overlooked, and species-level conservation has given priority to rare species at risk of imminent extinction [18]. It has become increasingly apparent, however, that common and widespread species with strong anthropogenic ties have not been immune to declines in abundance and extinction, and the effects are having profound consequences on the ecosystem [19-21].

Common species numbers have been found to disproportionately impact a large number of species and geographical areas with even relatively small reductions in abundance [22]. Blow flies have been considered poor ecological indicators due to their status as common, widespread, and highly mobile generalists lacking established correlations with ecosystem change [23,24]. It is, however, the common and widespread distribution of blow flies and domestic filth flies, together with their taxonomic diversity, rapid fluctuations in population density, and presence in anthropogenic environments $[25,26]$, that makes these species ideal for monitoring ecological changes created by environmental degradation and climatic change.

A global decline in insect abundance and species richness has been observed since the start of the 1900s, followed by a further decline during the 1950s and 1960s and an increasing decline in the last two decades [27]. A current study compiling data from 166 long-term surveys of insect assemblages showed that the strongest evidence for declines in terrestrial insect assemblages was found in North America [28]. Major insect taxonomic orders have seen a decline in species numbers, with some populations, mainly agricultural herbivores and nuisance pests, increasing [29]. A decline of $1 \%$ to $2 \%$ per annum is frequently reported, especially in areas affected by human activity [30]. This decline has been attributed to habitat loss, pollution, biological factors such as pathogens and introduced species, and climate change. Habitat loss in its many forms including deforestation, fragmentation, urbanization, and agricultural conversion is seen as a primary driver [30]. 
A decline in insect species is often accompanied by the presence of invasive species [31]. Blow fly range expansion has been noted for some time [32], with multiple recent examples, and thought largely attributable to climate change and globalization [33]. Lucilia cuprina Wiedemann, indigenous to Africa and Asia, is now found throughout the warm regions of the world. It has recently been recorded as far north as Indiana in the US, along with Chrysomya megacephala (Fabricius), another invasive species originally from Australasia [34]. Chrysomya rufifacies (Macquart), a native of Australasia, was first detected in Central America in 1978, and has since spread into the southern US in 1981 [35] and Ontario in 2004 [36]. This trend in range expansion is likely to increase in incidence with the continued change of urbanization and climate.

Changes in insect abundance and species richness in the larger region encompassing the site of the current and 1940s surveys have become increasing apparent in recent decades. A marked and ongoing decline of many moth and butterfly species has been recorded in Connecticut and neighboring states, including some previously common species and populations in habitats that remain rural, experiencing little difference in urbanization or agricultural practices [37]. The establishment of some southern species and the increase in abundance of previously rare species have also been documented, possibly attributable to a longer growing season and warmer summer temperatures [37]. Likewise, the abundance of mosquitoes in Connecticut has increased by close to $60 \%$ and species richness by $10 \%$ since 2001, with the total species richness highest in the southern portion of CT including New Haven, due to the northward range expansion of multiple species within the Aedes, Anopheles, Culex, and Psorophora genera (Diptera: Culicidae) [38]. Changes to flora have accompanied these changes in the insect population, with the northeastern United States now having the highest proportion of nonnative species in the continental United States [39].

At the time of the New Haven 1942-1944 survey, the authors reported that very few filth fly data existed for the northeastern United States. Today, this remains the case [40]. More data are needed to determine if the biodiversity decline seen in many of the major insect taxa is also being witnessed in Diptera. Data re lacking for most Diptera [27], with data only available on muscid flies [41], mosquitoes [38], and other flies including hoverflies [29]. The proximity of the current and historical survey sites enables the assessment of attributing factors such as land use change and climate and serves as a model for similarly highly urbanized established cities such as New Haven. This study compares current fly data to the data collected in 1942-1944 to assess changes in species diversity and relative abundance. Changes in land cover and climate were also assessed by examining weather data from the last 78 years and comparing present day land use to historical data to determine the effect if any of the environment. The current survey provides a much needed comparison to the fly data collected 78 years ago.

\section{Materials and Methods}

A hanging Diptera cone trap [42] baited with $200 \mathrm{~g}$ of raw pork meat was placed weekly from 9 a.m. to 4 p.m. from the beginning of June to the end of September in 2019 and 2020. The trap was hung approximately $1.5 \mathrm{~m}$ from the ground in an overgrown partly shaded lot between two buildings. The trap set out at the end of September 2020 was placed adjacent to a pig head to maximize collection for that time point. The fly population data collected were compared to the results of a study conducted in 1942-1944 approximately $2 \mathrm{~km}$ from the present day trap site. As species counts were not published for 1942, the 1943-1944 fly counts were used to compare fly populations across the two studies. In 1943-1944 a conical hoop flytrap [1,43] was placed twice a week and baited with a mix of feces and pooled mouse tissue. In the current study, calliphorids were identified using Whitworth's updated key [44], and non-calliphorids were identified using Dodge's 1953 key [45].

ArcGIS [46] was used to define current land cover by using a $5 \mathrm{~km}$ buffer projected out from the Yale New Haven Hospital, which encompassed the 1940s and current trap 
sites, and adding the 2016 National Land Cover Database (NLCD), the 2016 NLCD urban impervious surfaces data, and the Trust for Public Land urban heat island data. The NLCD land cover data include 19 categories of land use at $30 \mathrm{~m}$ resolution, and NLCD Urban imperviousness data represent the percentage of urban impervious surfaces such as roads and core urban areas over every $30 \mathrm{~m}$ pixel. The urban heat island data were generated from ground-level thermal sensors from the 2018 and 2019 summers and show the heat severity for every $30 \mathrm{~m}$ pixel using a 1 to 5 scale, with 5 being a heat area significantly above the mean for the city. Land cover changes were assessed using a 1954 USDA land cover map [47], 1985 land cover data from the UConn Centre for Land Use Education and Research (CLEAR), and USGS topographic maps from 1892, 1942, and 1954.

The city of New Haven is a coastal city located on the North-East Coast of the United States that has undergone significant changes in the landscape since the comparative fly survey conducted in the early 1940s. By the turn of the 20th century, New Haven was already a major industrial hub with a population of over 100,000. At the time of the 1940s fly survey, the city was a dense urban setting at its industrial peak with a population of approximately 160,000. In the 1950s, it underwent major urban renewal after the loss of population and industry. Large sections of the city were redeveloped, major highways were constructed, and residential housing booms occurred in adjacent suburban towns [48]. Today, New Haven is completely built out, except for sections of land designated for conservation such as parks and open space. The city is less dense and industrial, with a population of approximately 130,000 (US Census).

New Haven typically experiences a large range in temperature, both daily and annually, with January being the coldest month with a mean temperature of $0{ }^{\circ} \mathrm{C}$ and July being the hottest month with a mean temperature of $23^{\circ} \mathrm{C}$. Precipitation is normally evenly distributed throughout the year, with June being the wettest month with a mean rainfall of $26 \mathrm{~mm}$, and February the driest with an average of $14 \mathrm{~mm}$ (noaa.gov). Summers are now considered hotter and drier, and spring is arriving earlier with increased precipitation and heavier rainstorms [49].

\section{Statistical Analysis}

Temperature and rainfall data for the current 2019-2020 survey years were obtained from the NOAA Tweed Airport-New Haven weather station located approximately $7 \mathrm{~km}$ from the trap site. Weather data from the nearby city of Bridgeport, Connecticut, were obtained for 1942-1944 to analyze fly collection data from those years. While collection dates for the 1942-1944 data were not published, fly species counts were obtained from the published graphs, temperature data were averaged biweekly, and rainfall data totaled biweekly, to compare the historical fly collection data to temperature and rainfall data. A one-way analysis of variance (ANOVA) was used to determine if a statistically significant interaction between fly species counts and the maximum temperature four weeks prior to and on the day of trapping and rainfall four weeks prior to and on the day of trapping for 1942-1944 and 2019-2020.

Furthermore, to determine if species fly counts were significantly different across the two surveys and between years of each survey, $\mathrm{z}$ scores and $p$ values were computed. The Simpson's diversity index was used to measure the diversity of the fly population for both surveys, considering the number of species present as well as the relative abundance of each species. Rank distribution graphs were plotted to visualize species evenness.

\section{Results}

A total of 1352 flies were trapped across the two years, with the highest number of flies peaking on both years between the middle of June and early July. The number of species was highest in July in 2019 and in June and September in 2020. A total of 14 species were trapped with the number of species not exceeding 10 in any one month. Ninetyfive percent of the total overall count comprised of three species: Lucilia sericata (Meigen) $56.76 \%$, Lucilia coeruleiviridis Macquart $25.41 \%$, and Phormia regina (Meigen) $13.37 \%$. The 
three dominant species remained the same across the two years (Table 1). In 2019, L. sericata accounted for $35.97 \%$ of the total count, L. coeruleiviridis $39.68 \%$, and $P$. regina $18.71 \%$, and in 2020, L sericata accounted for $74.52 \%$ of the total count, L. coeruleiviridis $13.22 \%$, and $P$. regina $8.82 \%$, while all other species accounted for $1 \%$ or lower. Flies were also ranked according to an arbitrary number according to their abundance in each trap, and the top three species according to the overall arbitrary rank was the same as their rank according to overall count.

Table 1. Fly species trapped in the current 2019-2020 survey.

\begin{tabular}{|c|c|c|c|c|c|}
\hline \multicolumn{6}{|c|}{ 2019-2020 Traps } \\
\hline Species & $\begin{array}{c}\text { Position Based on } \\
\text { Sum of Arbitrary } \\
\text { Ranks }\end{array}$ & $\begin{array}{c}\text { Sum of Arbitrary } \\
\text { Ranks }\end{array}$ & Count Rank & $\begin{array}{c}\text { Sum of Total } \\
\text { Specimen Counts }\end{array}$ & $\begin{array}{c}\text { Percent of Overall } \\
\text { Count }\end{array}$ \\
\hline Lucilia sericata & 1 & 325 & 1 & 764 & 56.76 \\
\hline Lucilia coeruleiviridis & 2 & 317 & 2 & 342 & 25.41 \\
\hline Phormia regina & 3 & 208 & 3 & 180 & 13.37 \\
\hline Muscina stabulans & 4 & 70 & 5 & 9 & 0.67 \\
\hline Hylemya spp. & 5 & 61 & 4 & 13 & 0.97 \\
\hline Calliphora vicina & 6 & 60 & 7 & 6 & 0.45 \\
\hline Hydrotaea ignava & 7 & 48 & 6 & 8 & 0.59 \\
\hline Muscina assimilis & 8 & 41 & 8 & 4 & 0.30 \\
\hline Calliphora livida & 9 & 30 & 6 & 8 & 0.59 \\
\hline Lucilia silvarum & 10 & 29 & 8 & 4 & 0.30 \\
\hline Sarcophaga spp. & 11 & 28 & 9 & 3 & 0.22 \\
\hline Fannia spp. & 12 & 20 & 8 & 4 & 0.30 \\
\hline Musca domestica & 13 & 10 & 10 & 1 & 0.07 \\
\hline
\end{tabular}

Ninety-six percent of the total overall count in 1943-1944 also comprised only three species: L. sericata, 83.75\%; Lucilia illustris (Meigen), 7.48\%; and P. regina, 5.19\%, with L. sericata being the species with the highest number in $100 \%$ of the traps. In the current study, L.sericata remained the species with the highest overall trap number; however, L.sericata was trapped significantly less $(p<0.001)$, accounting for only $56.76 \%$ of the overall numbers, and was the species with the highest number in 59\% of the traps. In the current survey, $L$. coeruleiviridis and P. regina counts were significantly higher in the current survey $(p<0.001)$, with $L$. coeruleiviridis surpassing $L$. sericata as the highest trapped species in $41 \%$ of the traps and $P$. regina surpassing $L$. sericata as the highest trapped species in $11 \%$ of the traps. L.coeruleiviridis accounted for $25.41 \%$ of all flies in the current survey, while it was relatively rare in 1943-1944, accounting for only $0.39 \%$ of the total count. The numbers of Calliphora vicina (Robineau-Desvoidy), Hylemya spp., and Hydrotaea ignava specimens were also significantly higher in the current survey than the numbers trapped in the 1943-1944 traps $(p<0.01)$. In the 1940s, L. illustris was the second-highest species trapped; however, it was not trapped in the current survey $(p<0.001)$. The number of Sarcophaga spp. specimens trapped in the current survey was also significantly lower $(p<0.001)$ in the current survey (Tables 2-4).

Sixteen additional species were trapped in the 1940s survey compared to the current survey. All of the species trapped in the current survey were also trapped in the 1940s survey, except for one species, Calliphora livida Hall. Diversity was higher in the 1943-1944 survey compared to the current survey. The Simpson's diversity index showed higher diversity in 1943-1944 ( $\mathrm{D}=0.7098)$ compared to 2019-2020 ( $\mathrm{D}=0.4044)$. Rank abundance distribution graphs show low species evenness across both surveys as a result of the higher abundance of the three to four top-ranking species (Figure 1). 
Table 2. Fly species trapped in the 1943-1944 survey.

\begin{tabular}{|c|c|c|c|c|c|}
\hline \multicolumn{6}{|c|}{ 1943-1944 Traps } \\
\hline Species & $\begin{array}{c}\text { Position Based on } \\
\text { Sum of Arbitrary } \\
\text { Ranks }\end{array}$ & $\begin{array}{c}\text { Sum of Arbitrary } \\
\text { Ranks }\end{array}$ & Volume Rank & Sum of Volume in cc & $\begin{array}{c}\text { Percent of Overall } \\
\text { Count }\end{array}$ \\
\hline Lucilia sericata & 1 & 803 & 1 & 21,698 & 83.75 \\
\hline Phormia regina & 2 & 593 & 3 & 1344 & 5.19 \\
\hline Lucilia illustris & 3 & 463 & 2 & 1937 & 7.48 \\
\hline Sarcophaga spp. & 4 & 347 & 4 & 304 & 1.17 \\
\hline Calliphora vicina & 5 & 187 & 13 & 36 & 0.14 \\
\hline $\begin{array}{c}\text { Lucilia } \\
\text { coeruleiviridis }\end{array}$ & 6 & 177 & 7 & 100 & 0.39 \\
\hline Hylemya spp. & 7 & 155 & 5 & 102 & 0.39 \\
\hline $\begin{array}{l}\text { Cynomyopsis } \\
\text { cadaverina }\end{array}$ & 8 & 151 & 9 & 68 & 0.26 \\
\hline Muscina stabulans & 9 & 143 & 8 & 75 & 0.29 \\
\hline Fannia spp. & 10 & 121 & 6 & 101 & 0.39 \\
\hline Musca domestica & 11 & 103 & 11 & 49 & 0.19 \\
\hline $\begin{array}{l}\text { Calliphora } \\
\text { vomitoria }\end{array}$ & 12 & 83 & 12 & 37 & 0.14 \\
\hline Hydrotaea ignava & 13 & 70 & 10 & 58 & 0.22 \\
\hline
\end{tabular}

Table 3. Comparison of fly species trapped in the 1940s and current survey. Species with a significantly different fly count between surveys are in bold.

\begin{tabular}{|c|c|c|c|c|c|c|c|c|}
\hline \multirow[b]{2}{*}{ Species } & \multicolumn{3}{|c|}{ 1943-1944 Traps } & \multicolumn{3}{|c|}{ 2019-2020 Traps } & \multicolumn{2}{|c|}{ Difference } \\
\hline & $\begin{array}{c}\text { Arbitrary } \\
\text { Rank }\end{array}$ & $\begin{array}{c}\text { Volume } \\
\text { Rank }\end{array}$ & $\begin{array}{c}\text { Percent of } \\
\text { Overall } \\
\text { Count }\end{array}$ & $\begin{array}{c}\text { Arbitrary } \\
\text { Rank }\end{array}$ & $\begin{array}{l}\text { Count } \\
\text { Rank }\end{array}$ & $\begin{array}{c}\text { Percent of } \\
\text { Overall } \\
\text { Count }\end{array}$ & z Score & $p$ Value \\
\hline L. sericata & 1 & 1 & 83.75 & 1 & 1 & 56.76 & -25.36 & $<0.0001$ \\
\hline P. regina & 2 & 3 & 5.19 & 3 & 3 & 13.37 & 12.73 & $<0.0001$ \\
\hline L. illustris & 3 & 2 & 7.48 & 0 & 0 & 0 & -10.41 & $<0.0001$ \\
\hline Sarcophaga spp. & 4 & 4 & 1.17 & 11 & 9 & 0.22 & -3.22 & $<0.001$ \\
\hline C. vicina & 5 & 13 & 0.14 & 6 & 7 & 0.45 & 2.82 & $<0.01$ \\
\hline L. coeruleiviridis & 6 & 7 & 0.39 & 2 & 2 & 25.41 & 70.77 & $<0.0001$ \\
\hline Hylemya spp. & 7 & 5 & 0.39 & 5 & 4 & 0.97 & 3.21 & $<0.001$ \\
\hline Cy. cadaverina & 8 & 9 & 0.26 & 0 & 0 & 0 & -1.87 & Not sig \\
\hline M. stabulans & 9 & 8 & 0.29 & 4 & 5 & 0.67 & 2.45 & Not sig \\
\hline Fannia spp. & 10 & 6 & 0.39 & 12 & 8 & 0.30 & -0.52 & Not sig \\
\hline M. domestica & 11 & 11 & 0.19 & 13 & 10 & 0.07 & -1.00 & Not sig \\
\hline C. vomitoria & 12 & 12 & 0.14 & 0 & 0 & 0 & -1.37 & Not sig \\
\hline H. ignava & 13 & 10 & 0.22 & 7 & 6 & 0.59 & 2.71 & $<0.01$ \\
\hline C. livida & 0 & 0 & 0 & 10 & 6 & 0.59 & 12.37 & $<0.0001$ \\
\hline M. assimilis & 14 & 14 & Unknown * & 8 & 8 & 0.30 & $\mathrm{n} / \mathrm{a}$ & $\mathrm{n} / \mathrm{a}$ \\
\hline L. silvarum & 14 & 14 & Unknown * & 9 & 8 & 0.30 & $\mathrm{n} / \mathrm{a}$ & $\mathrm{n} / \mathrm{a}$ \\
\hline
\end{tabular}


Table 4. Differences in fly species trapped in the current and 1940s surveys.

\begin{tabular}{ccc}
\hline $\begin{array}{c}\text { Species Found in Both the 1940s Traps } \\
\text { and the 2019-2020 Traps }\end{array}$ & $\begin{array}{c}\text { Species Found in the 1940s Traps but } \\
\text { not in the 2019-2020 Traps }\end{array}$ & $\begin{array}{c}\text { Species Found in 2019-2020 Traps but } \\
\text { not in 1940s Traps }\end{array}$ \\
\hline Lucilia sericata & Lucilia illustris + \\
Phormia regina & Calliphora vomitoria $\dagger$ \\
Lucilia coeruleiviridis & Cochliomyia macellaria \\
Lucilia silvarum & Cynomyopsis cadaverina \\
Calliphora vicina & Protophormia terraenovae \\
Sarcophaga spp. & Pollenia rudis + \\
Muscina stabulons & Helina spp. \\
Hylemya spp. & Myospila meditabunda \\
Fannia spp. & Scathophaga spp. \\
Muscina domestica & Stomoxys calcitrans \\
Muscina assimilis & Chrysomyza splendida \\
Hydrotaea ignava & Euxesta notata \\
& Delphinia picta \\
& Ptecticus trivitattus \\
& Syritta pipiens \\
& Toxomerus geminatus \\
\hline
\end{tabular}

† trapped in Hartford County in same time period.

\section{3 - 1944 Rank abundance distribution}

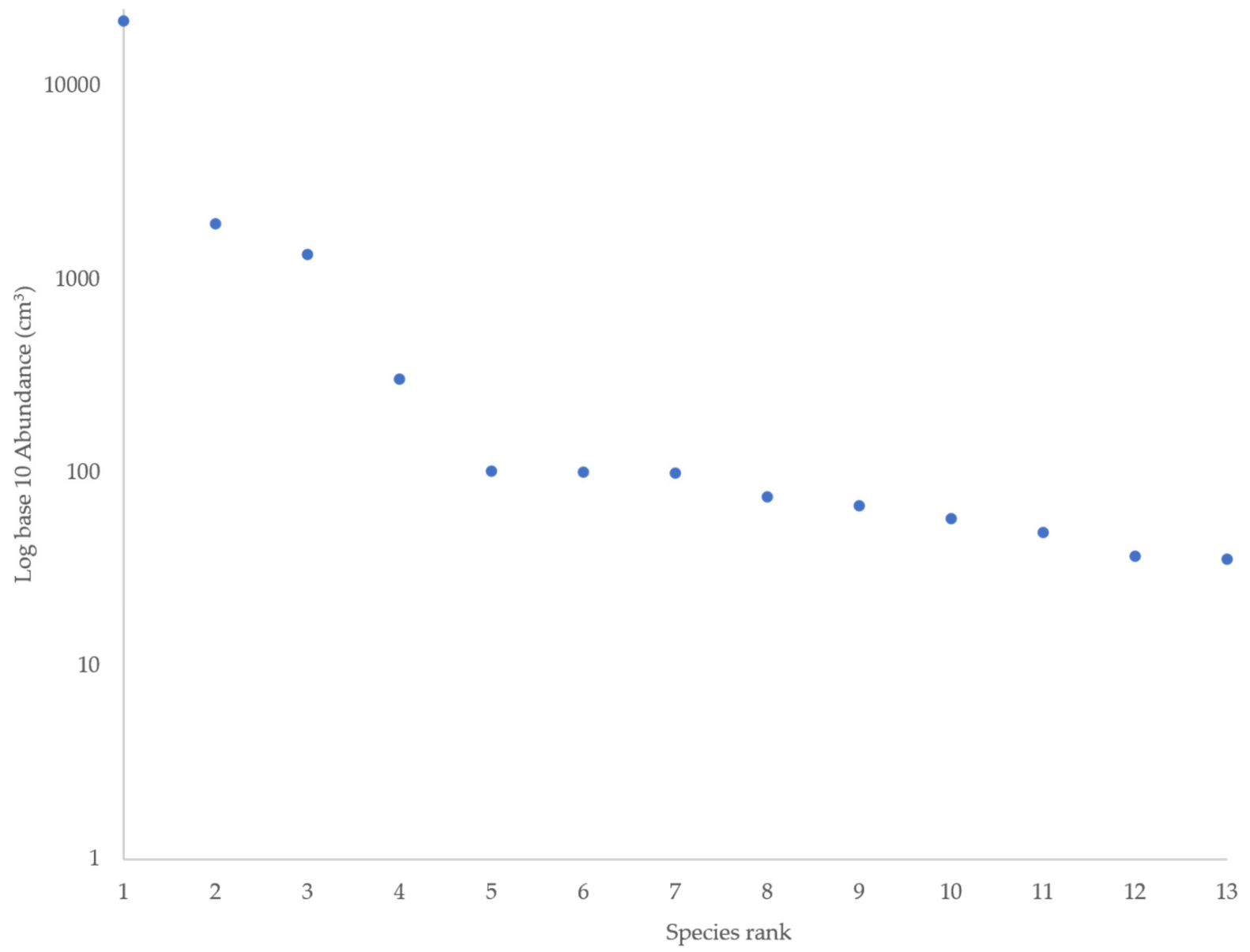

(a)

Figure 1. Cont. 


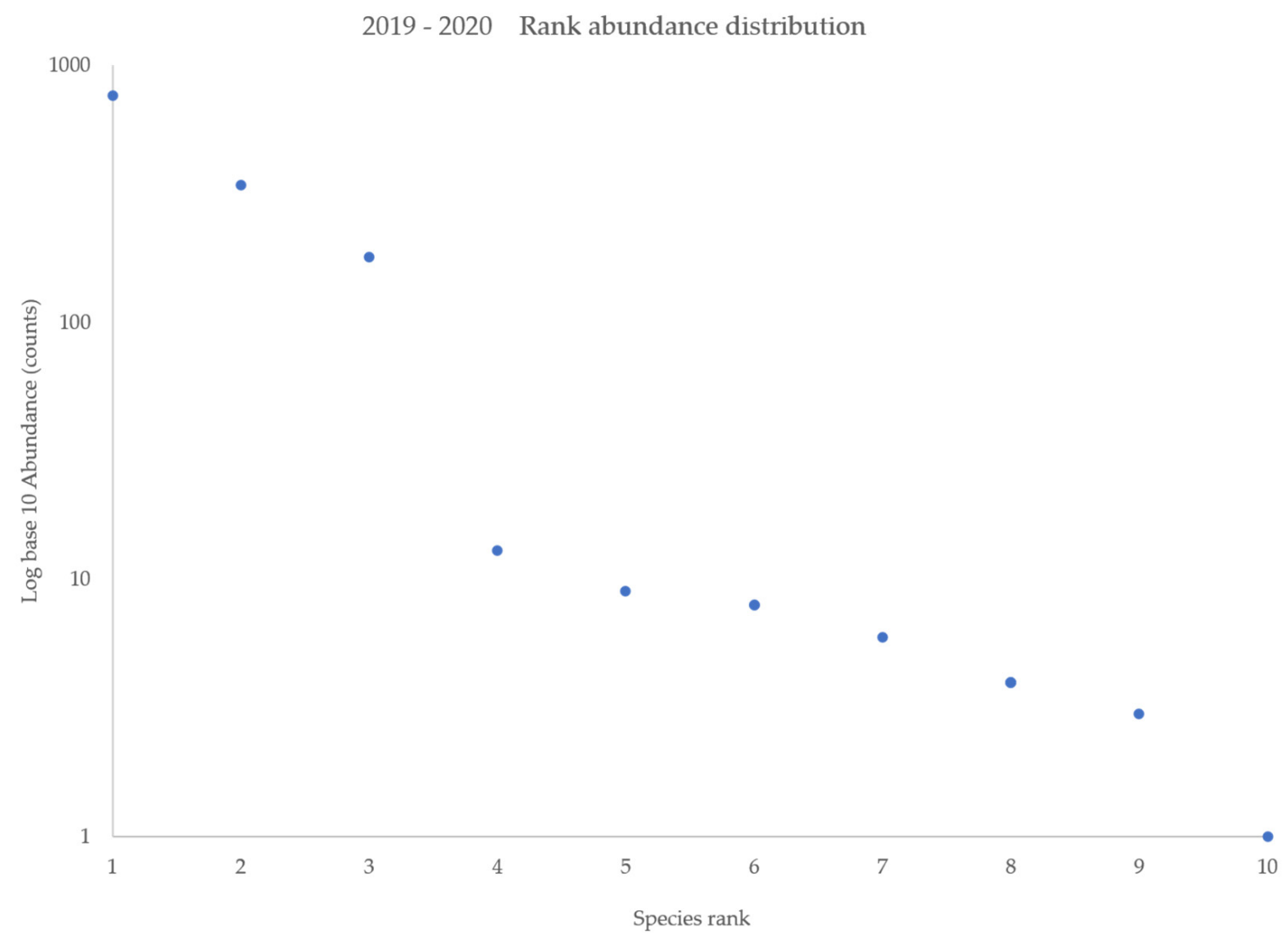

(b)

Figure 1. Rank abundance distributions for the (a) 1943-1944 survey and (b) 2019-2020 survey. Steep gradients are observed in both the 1940s and the present-day surveys, indicating low species evenness due to the much higher abundances of species ranked 1-4 in the 1940s and species ranked 1-3 in the present-day survey.

Fly populations fluctuated markedly from year to year in the 1940s survey and in the current survey. Significantly higher numbers of L. sericata were trapped in 2019 compared to $2020(\mathrm{z}=14.23, p<0.001)$, and significantly lower numbers of $P$. regina $(\mathrm{z}=-5.31$, $p<0.001)$ and L. coeruleiviridis $(\mathrm{z}=-11.11, p<0.001)$ were trapped in 2019 compared to 2020. In the 1940s surveys, L. sericata was trapped in high numbers across the three years, while P. regina and L. illustris numbers fluctuated greatly (Table 3).

In the current survey, the maximum daily temperature four weeks prior to the trap date had a significant effect on $P$. regina and C. livida numbers, with an increase in temperature resulting in a significant increase in $P$. regina $\left.\left(\mathrm{F}_{(11,15}\right)=11.34, p<0.001\right)$ and C. livida $(\mathrm{F}(3,23)=13.08, p<0.001)$ counts (Figure 2). The rainfall four weeks prior to the trap date had a significant effect on $L$. sericata and L. coeruleiviridis numbers, with an increase in rainfall resulting in a significant increase in L. sericata $(\mathrm{F}(21,5)=14.55, p<0.01)$ and $L$. coeruleiviridis $(\mathrm{F}(16,10)=4.43, p=0.01)$ counts (Figure 3). No correlation was observed between temperature and rainfall for the remaining trapped species. 


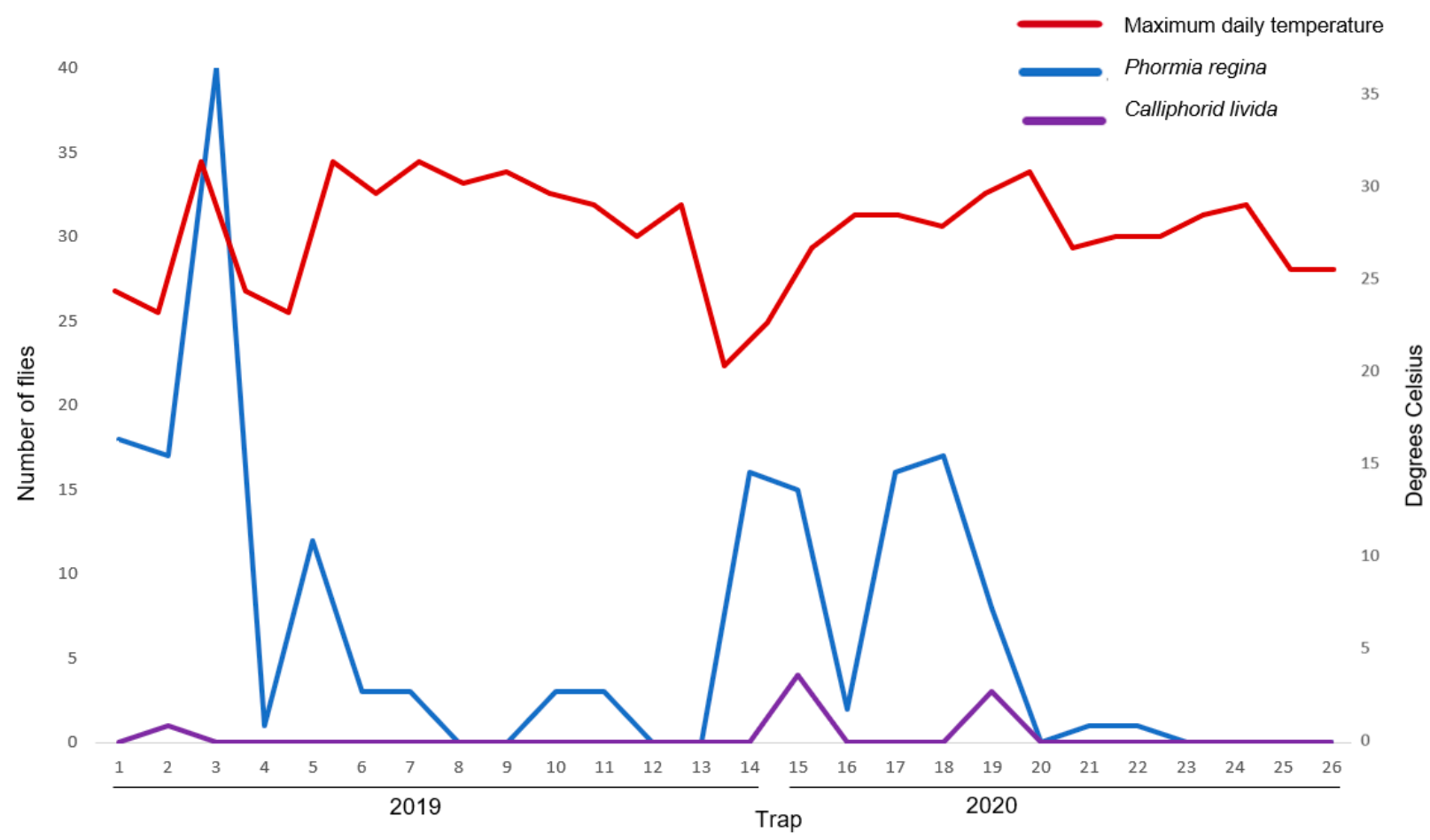

Figure 2. Maximum daily temperature and Phormia regina and Calliphora livida numbers for 2019-2020 traps.

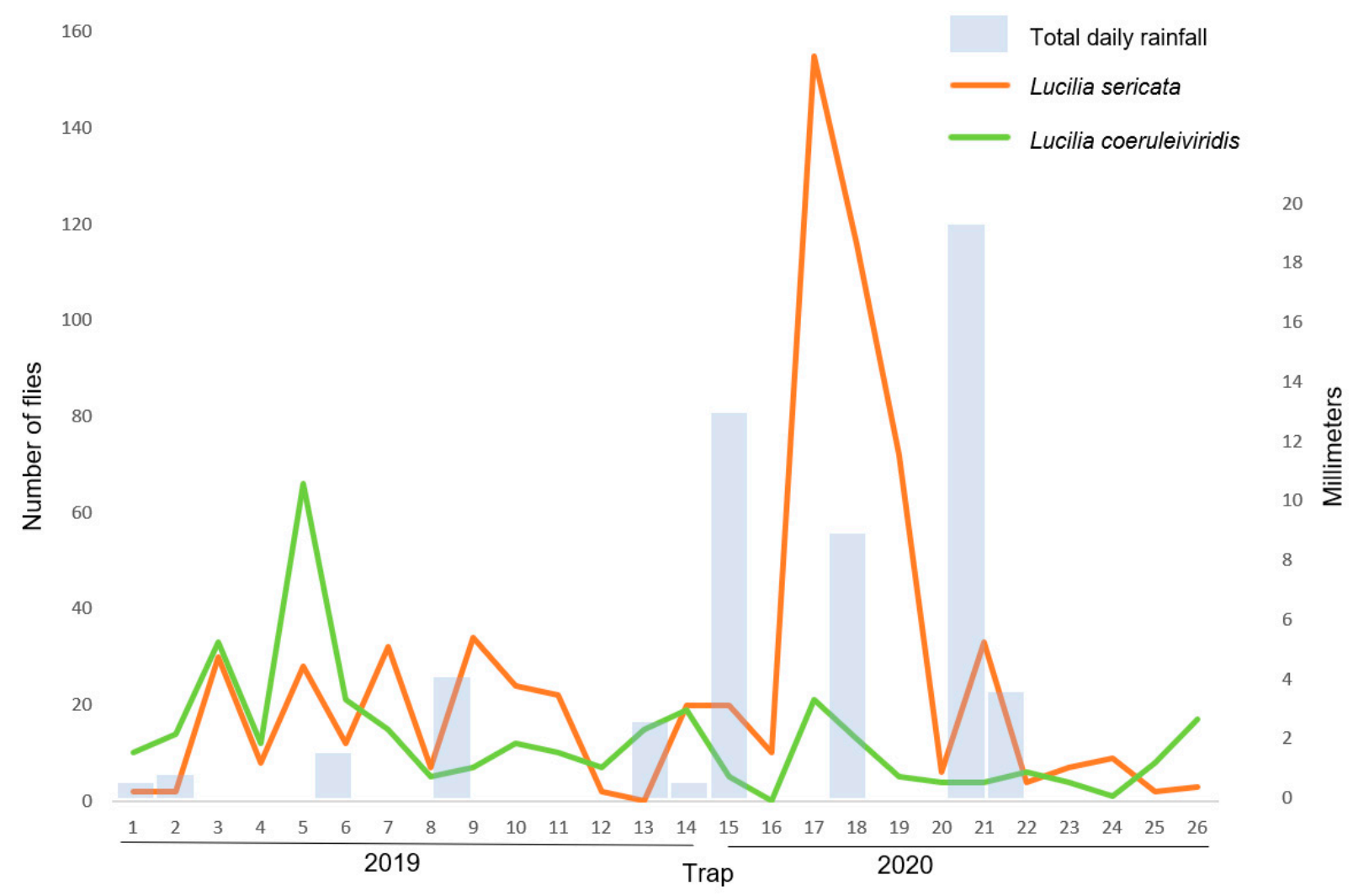

Figure 3. Total daily rainfall and Lucilia sericata and Lucilia coeruleiviridis numbers for 2019-2020 traps.

Temperature and precipitation also influenced P. regina, L. coeruleiviridis, and C. vicina counts in 1942-1944. The maximum daily temperature had a significant effect on $L$. coeruleiviridis counts on the trap day $(\mathrm{F}(13,136)=2.42, p<0.01)$ and four weeks prior to the trap day $(\mathrm{F}(13,136)=5.46, p<0.001)$, on $P$. regina counts on the trap day $(\mathrm{F}(21,128)=3.89$, 
$p<0.001)$, and four weeks prior to the trap day $(\mathrm{F}(21,128)=2.67, p<0.001)$, and C. vicina counts on the trap day $(\mathrm{F}(20,142)=2.87, p<0.001)$. The rainfall four weeks prior to the trap date also had a significant effect on $L$. coeruleiviridis numbers $(\mathrm{F}(13,136)=2.53, p<0.01)$ and $C$. vicina numbers $(\mathrm{F}(20,142)=2.12, p<0.01)$. No interaction between temperature and rainfall was observed for L. sericata and L. illustris 1942-1944 trap numbers.

The USGS topography map of New Haven from 1892 shows that New Haven was already an established city by 1900. The USGS topography map of New Haven from 1954 shows the original coastline, and the 1954 land cover map shows the majority of land in the $5 \mathrm{~km}$ buffered area as developed and a change in coastline. Comparative land cover data from 1985 to 2015 show that the changes in landcover have been minimal in this 30 year period, with only small areas of forest changing to developed and other classes changing to turf and grass (Figure 4). Land cover has changed little across the state of Connecticut from 1985 to 2015 with a 3.1\% increase in developed land, a 1.6\% increase in turf and grass, a 3.5\% decrease in forested land, and a 1.4\% decrease in agricultural fields. In this 30 year period, New Haven has gained 275 acres of developed land and lost 152 acres of forested land [50] (Figure 5).

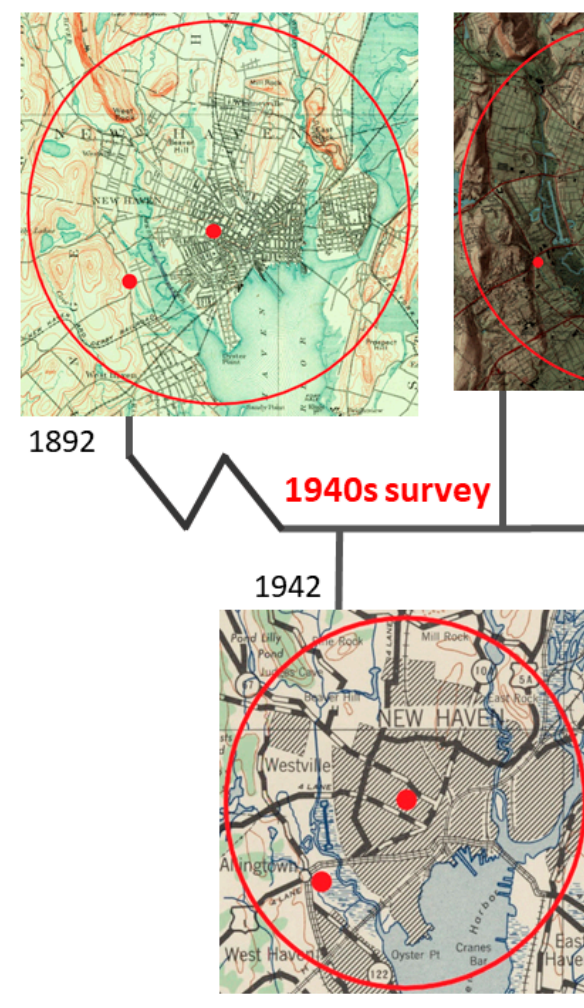

Figure 4. Topography and land cover of New Haven, CT, from 1892-2015. Source: 1892 [51]; 1942 [52]; 1954 [53]; 1954 land cover [47]; 1985 and 2015 land cover [50]; 2020 [54].

Present-day land cover analysis described the land in the $5 \mathrm{~km}$ buffer as $81 \%$ developed, $12 \%$ open water, and $3 \%$ deciduous forest, with all other land cover categories at $1 \%$ or less, and $51 \%$ of the developed surfaces having an imperviousness percentage above $50 \%$ ( $68 \%$ above $25 \%$ and $22 \%$ above $75 \%$ ). Heat island data categorized over half of the buffered area as slightly hotter than the mean for the city, with multiple spots categorized as significantly higher (Figure 6). Tree canopy percentage is low at $16 \%$ at the original trap location [55]. 

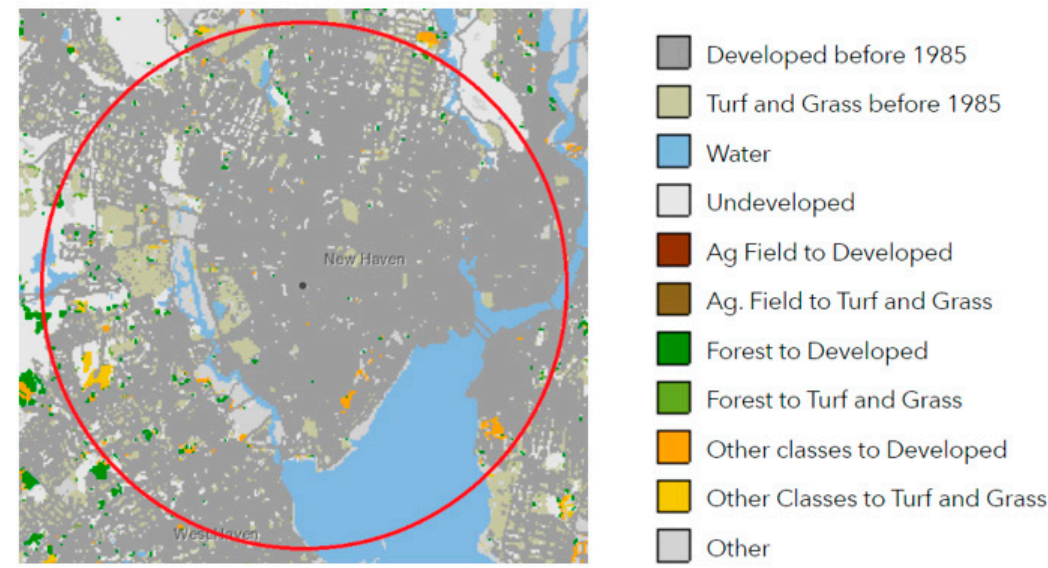

Figure 5. Land cover change 1985 to 2015 (UConn CLEAR).
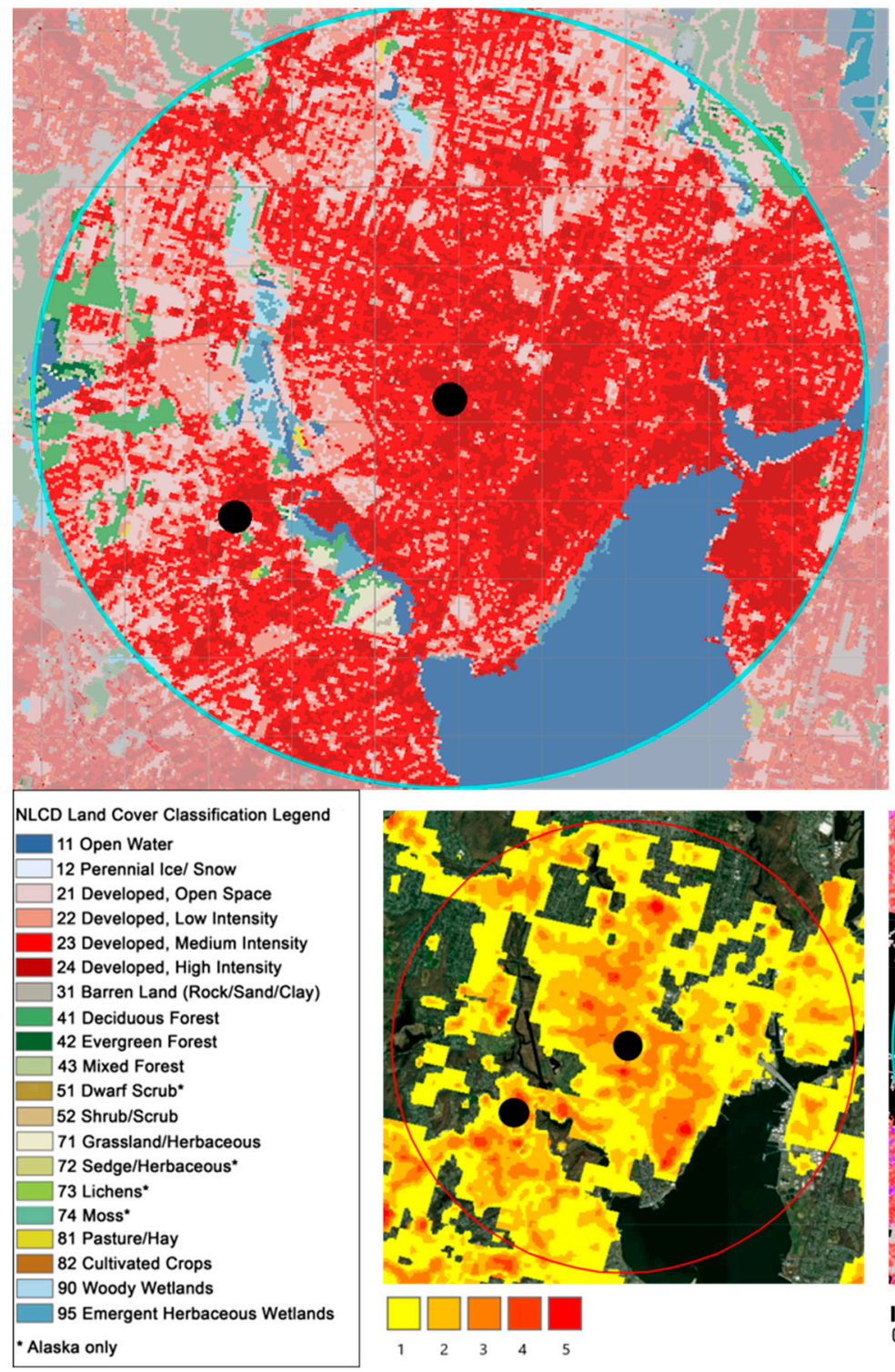

\begin{tabular}{|l|c|}
\hline Land cover & $\%$ \\
\hline Open water & 12 \\
\hline Developed open space & 11 \\
\hline Developed low intensity & 19 \\
\hline Developed med intensity & 34 \\
\hline Developed high intensity & 17 \\
\hline Barren land & $<1$ \\
\hline Deciduous forest & 3 \\
\hline Evergreen forest & $<1$ \\
\hline Mixed forest & $<1$ \\
\hline Shrub & $<1$ \\
\hline Grassland & $<1$ \\
\hline Pasture & $<1$ \\
\hline Crops & $<1$ \\
\hline Woody wetlands & 1 \\
\hline Emergent wetlands & 1 \\
\hline
\end{tabular}
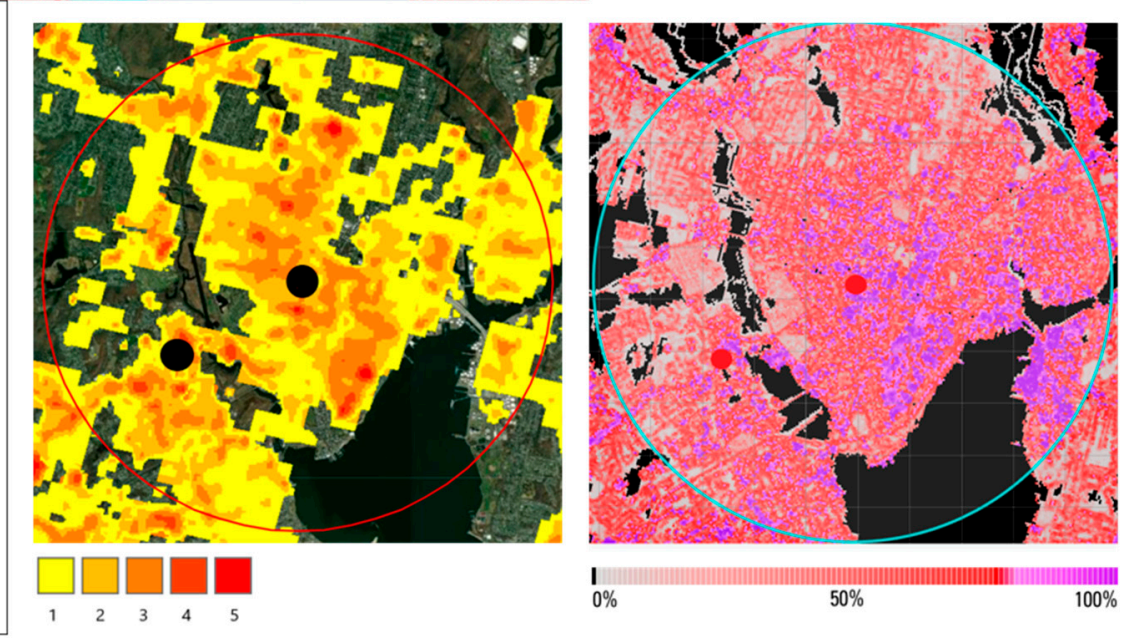

Figure 6. Current land cover characterization of $5 \mathrm{~km}$ buffered area around trap sites for current survey (left marker) and 1940s survey (right marker). Clockwise: Land cover 2016 (NLCD); urban impervious surfaces 2016 (NLCD); urban heat island severity 2019-2020 (The Trust for Public Land). The urban heat island scale 1 to 5 scale is described as 1: heat area slightly above the mean for the city and 5 : heat area significantly above the mean for the city. 


\section{Discussion}

Results of this two-year study indicate the domestic filth fly population has changed in New Haven in the last 78 years. The population is less diverse with decreased species richness and changes in the relative abundance of species. The biggest change in the fly population compared to 78 years ago includes the inclusion of less species overall, the decreased numerical dominance of $L$. sericata, the increased abundance of $L$. coeruleiviridis, and the absence of L. illustris. Low species evenness was observed across both surveys due to the relatively much higher abundance of the highest-ranked species. In the 1940s, the numerical dominance of $L$. sericata, and also the relatively higher abundance of $P$. regina, L. illustris, and Sarcophaga species compared to all other trapped species, reduced species evenness. Species evenness was also reduced in the present-day survey as a result of the disproportionately higher abundance of the top three species: L. sericata, L. coeruleiviridis, and P. regina.

At the time of the 1940s survey, L. sericata had not yet achieved cosmopolitan status due to its absence in regions including Central and South America. Today, this common fly is distributed worldwide [56,57] with varying degrees of synanthropy $[58,59]$ and often abandons its natural rural habitat in favor of human settlements especially in colder regions [8,60-62]. Lucilia sericata has adapted by being generalistic and opportunistic, feeding on a wide variety of food substrates, and being a facultative parasite, notorious for causing sheep myiasis [63]. Lucilia sericata remained the most abundant species trapped overall; however, it was not always the most abundant species in weekly traps, as reported in the 1940s. Temperature did not significantly affect $L$. sericata numbers in the current study nor the 1940s survey, while rainfall was a factor in the current survey. Four weeks prior to the trap date spans the entire lifecycle of the trapped specimens and coincides with the approximate time of oviposition [26]. The rainfall four weeks prior to the trap date had a significant positive effect on $L$. sericata numbers. This finding is supported by research showing L. sericata colonizes carcasses in water (along with only Cochliomyia macellaria and Sarcophaga bullata) [64], and the species' ability to survive submerged in water as pupae is longer than C. vicina [65] and C. vomitora [66]. Lucilia sericata numbers fluctuated greatly between the first and second year of the current survey with the second year showing significantly higher numbers of $L$. sericata, coinciding with a much wetter year.

Lucilia coeruleiviridis was rarely trapped in the 1940s survey and in the 1950s in New York [67] while it was the second highest trapped species in the current survey. Distribution of the species is throughout the Nearctic region $[68,69]$ and has recently expanded into Canada $[68,70]$. The species was previously listed as common in the southwestern US [56], while it is now a dominant blow fly species on the US East Coast, especially in the summer, as reported in Virginia [71], Florida [72], and New Jersey [73], where it is often reported as the most abundant species, the first to arrive on carrion, and the first to complete development [72]. High numbers of the species, second only to L. sericata, were also trapped in Hartford County, approximately $65 \mathrm{~km}$ north of the New Haven trap site [42]. Temperature and rainfall both significantly affected L. coeruleiviridis numbers in the 1940s survey. In the current survey, temperature did not have a significant effect on L. coeruleiviridis numbers, while rainfall four weeks prior to the trap date, had a significant positive effect, as with $L$. sericata. However, unlike $L$. sericata, L. coeruleiviridis had significantly lower numbers in the second (wetter) year of the current survey, suggesting other factors may have limited L. coeruleiviridis numbers in the second year, such as the high abundance of $L$. sericata, a species with a very similar developmental time. Research has shown L. coeruleiviridis to oviposit on carcasses in water at higher numbers than P. regina [74]; however, no data could be found comparing L. coeruleiviridis and L. sericata. Analysis of the 1942-1944 data showed that $L$. coeruleviridis numbers were also significantly affected by rainfall four weeks prior to the trap date, as were the maximum daily temperature on the trap date and four weeks prior, unlike L. sericata.

Phormia regina is found throughout most of the northern continents of the world, [75], is a secondary myiasis producer, and one of the primary species used to indicate the 
postmortem interval in human deaths throughout North America [76]. Phormia regina was the third highest trapped species in both the 1940s survey and in the current survey, with percentages significantly higher in the current study. The maximum temperature four weeks prior to the trap date had a significant effect on $P$. regina numbers, with an increase in temperature resulting in a significant increase in numbers. Analysis of the 1942-1944 data also showed that the temperature four weeks prior to the trap date, as well as the temperature on the trap date, significantly affected $P$. regina numbers. The species is typically considered a cold weather fly throughout most of the United States but has been recorded in large numbers during the summer in Virginia [71], Kansas [77], and California [78]. Phormia regina numbers also fluctuated significantly between Years 1 and 2 of the current survey, with numbers lower in the second year when L. sericata numbers were greater. Past research has shown the interaction between P. regina and L. sericata to be either competitive or facilitative, depending on temperature and larvae stage [79].

Lucilia illustris was the second most abundant fly in the 1940s survey and the most abundant fly together with L. sericata trapped in 1959-1960 in New Haven [80]. This was in sharp contrast to numbers captured in New York City in 1953 where the species comprised of only $1 \%$ of the total trapped [67]. Lucilia illustris was absent from the current New Haven traps. In nearby surveys, the species has only been trapped in very low numbers in Hartford county in 2019 and not in 2020 [42] and in very low numbers in New Jersey in 2011-2013 but not in 2014 [81]. The species is still currently one of the most abundant necrophagous Diptera in areas such as New Brunswick, Canada, together with P. regina [82] and was found to be the numerically dominant species in southern Finland for 15 years [83].

Lucilia illustris is found throughout the Holarctic and Oriental regions [68] and is responsible for secondary facultative myasis in livestock [84]. The species exhibits varying degrees of synanthropy, depending on the region. In Finland, L. illustris demonstrates no synanthropy [85], while in Central London, it shows a preference for urban settings [86]. Research on the competition of fly species in southern Finland showed that the survival of L. illustris declined even at low densities compared to other species, possibly related to the observed voracious appetite of L. illustris [83]. Similar findings were found in New Brunswick, Canada, with L. illustris overrepresented in small bait traps compared to carcasses, thought to be the result of the species' inability to compete with the dominant species on carcasses [82]. While it is difficult to say with certainty why the number of $L$. illustris trapped has declined in the New Haven region and nearby areas, the substantial change in abundance apparent between the surveys completed in the 1940s to that completed in New York City a decade later and the current survey suggest that the species' numbers have declined as a result of urbanization.

Calliphora livida was not trapped in the 1940s survey, while it was trapped in the current survey. Calliphora viridescens Robineau-Desvoidy, thought to be the same species at the time, was also not trapped. Calliphora livida is found throughout the Nearctic region $[68,69]$ and was caught in high numbers in the late 1940s and 1950s during the first week of May in Ontario, Canada, and in the US states Georgia and Wisconsin [87]. Given that the species was only first described by Hall in 1948, it is possible that the species was misidentified as C. vicina, a similar species, in the 1940 s surveys. The number of $C$. vicina specimens trapped were significantly higher in the current survey than the number trapped in the 1943-1944 traps. Analysis of the 1942-1944 data also showed that the temperature on the trap date and the rainfall four weeks prior had a significant effect on $C$. vicina numbers. Calliphora vicina is a cosmopolitan species closely associated with humans [58] and is ranked as the heaviest potential sanitary risk in Argentina along with L. sericata on Mihalyi's danger index, which takes into account the fly's habits in relation to infection transmission and the size of the fly [88].

Characterization of land cover in the $5 \mathrm{~km}$ buffer surrounding the trap sites has demonstrated that almost all the land in this area is now developed, with only $7 \%$ of the land undeveloped. Over half of these developed areas in the buffered area are impervious. Impervious surfaces are defined as any material that prevents the infiltration of water 
into the soil [89]. Such surfaces are considered a key environmental indicator as they are linked to detriments beyond the immediate habitat loss, as they prevent natural pollutant processing in the soil, transport pollutants into the waterways, and are linked to an increase in ambient temperature, soil compaction, and soil and air pollution [89,90]. Areas with larger areas of impervious surfaces are found to have fewer flying arthropods overall, especially Hemiptera, Araneae, and Diptera [91], and are found to be the key factor affecting bee assemblages [90].

Most of the land cover changes that took place in the surveyed area took place long before the comparative 1940s survey, with the region having a long history of anthropogenic change coinciding with the length of time since European settlement. A decade before the 1940s survey, rivers in the $5 \mathrm{~km}$ buffered area were dredged, and considerable areas of salt marshes were filled in. Changes that occurred since the 1940s survey are also significant, especially major changes to the coastline. During the 1950s and 1960s, tidal wetlands were filled for the construction of a interstate highway, dramatically changing the coastline, and by $1970,60 \%$ of tidal wetlands had been destroyed [92]. Such changes have created opportunity for some species but may have been the tipping point for several other species already stressed in an environment subjected to a prolonged period of industrialization and urbanization.

Since the 1940s survey, temperature, precipitation, and the number of heavy rainfall events have increased in the trapped region. Since 1944, the average temperature in New Haven has increased by 1.54 degrees Celsius, and average precipitation has increased by $78 \mathrm{~mm}$ (Figure 7) [93]. From 1960 to 2019, the annual number of heavy rainfall events (three consecutive days with cumulative precipitation of three inches or more) significantly increased [94]. Like land cover changes, climatic changes were also evident before the 1940s survey, with the mean temperature for the years 1907-1948 recorded at 1.3 degrees Celsius warmer than the 1780-1822 mean. Flies are likely to be among the species that respond positively to a warmer climate, with even small increases in temperature resulting in large increases in fly population density [26]. Temperature has been shown to be the primary weather variable that affects trap numbers of L. cuprina [95]. Overall percentages of the numbers of $P$. regina, C. vicina, L. coeruleiviridis, and possibly C. livida all increased since the 1940s survey, suggesting that the heat-tolerance for these species has increased, whereas $L$. sericata, L.illustris, and Sarcophaga species, along with several other less-trapped species, have decreased in abundance. It is interesting to note that the species that increased in abundance since the 1940s (P.regina, C. vicina and L. coeruleiviridis) were also the species that showed a significant interaction with temperature in the 1940s, while the species that showed a decrease in abundance (L. sericata and L. illustris) did not show an interaction with temperature in the 1940s. It is difficult to assess whether such changes in abundance are the result of weather changes due to the lack of additional timepoints between the two surveys and due to the correlation between climate, land use changes, and human behavior that in turn feed back into climate change [96]. Temperature increase is exacerbated in urban areas due to heat islands resulting from a combination of impervious surfaces and human activity, resulting in pockets of heat often as much as $12{ }^{\circ} \mathrm{C}$ hotter than adjacent areas [97]. The buffered trap area includes many heat islands including several of Level 5 severity, exposing species within the area to temperature increases higher than surrounding areas.

Urbanization has drastic and increasingly widespread effects, replacing natural systems with smaller sealed fragments of habitat [98]. Key factors such as local climate and nutrient availability are changed, and the structure of ecological communities is altered [99]. As urbanization exposes organisms to these novel environmental challenges, species richness and diversity decline [100,101] and biotic homogenization increases [98]. Differences in the competitive abilities of fly species when coexisting in these patchy resources needed for food and oviposition lead to the ecological displacement and local extinction of some and the prevalence of others [102,103]. This loss of diversity in developed areas has been demonstrated in other fly communities, with calliphorids found to be more diverse in natural areas compared to artificial clearings in Brazilian Amazon [25,104], Argentina [105], and 
across Canada [106], while an increase of abundance has been observed in sarcophagids in cleared land [25]. Biotic homogenization was already apparent in the 1940s, with L. sericata accounting for 80 and $90 \%$ of the volume of all flies trapped, and continues today, driven by the hyper-proliferation of a limited number of species in the population. In the $1940 \mathrm{~s}, 96 \%$ of the total number of flies was represented by three species, and this trend continues today, with $95 \%$ of the total represented by three species. While L. sericata remains an abundant species in the region, $P$. regina and especially $L$. coeruleiviridis have increased in abundance, while L. illustris, previously the second-most-abundant species, now appears to be absent.

New Haven County, Connecticut Average Temperature

July-June

1944-2020 Trend

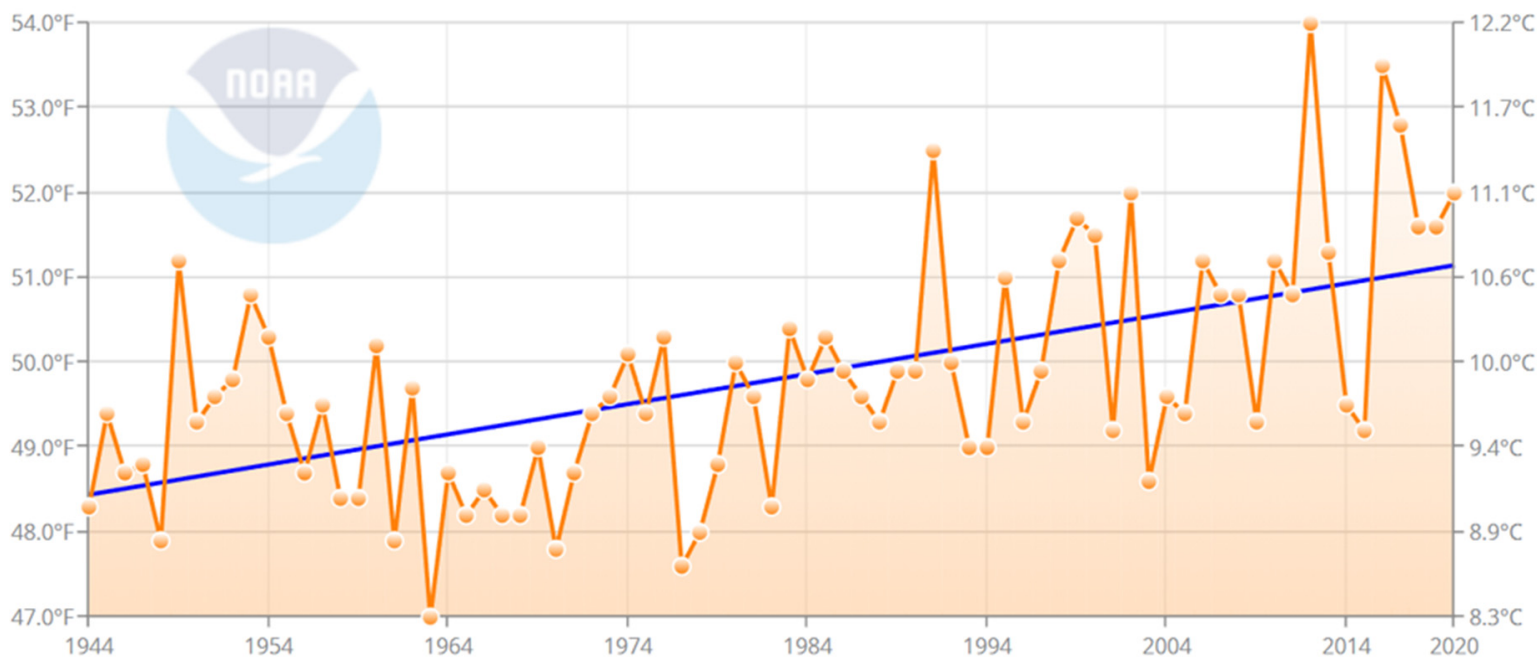

New Haven County, Connecticut Precipitation

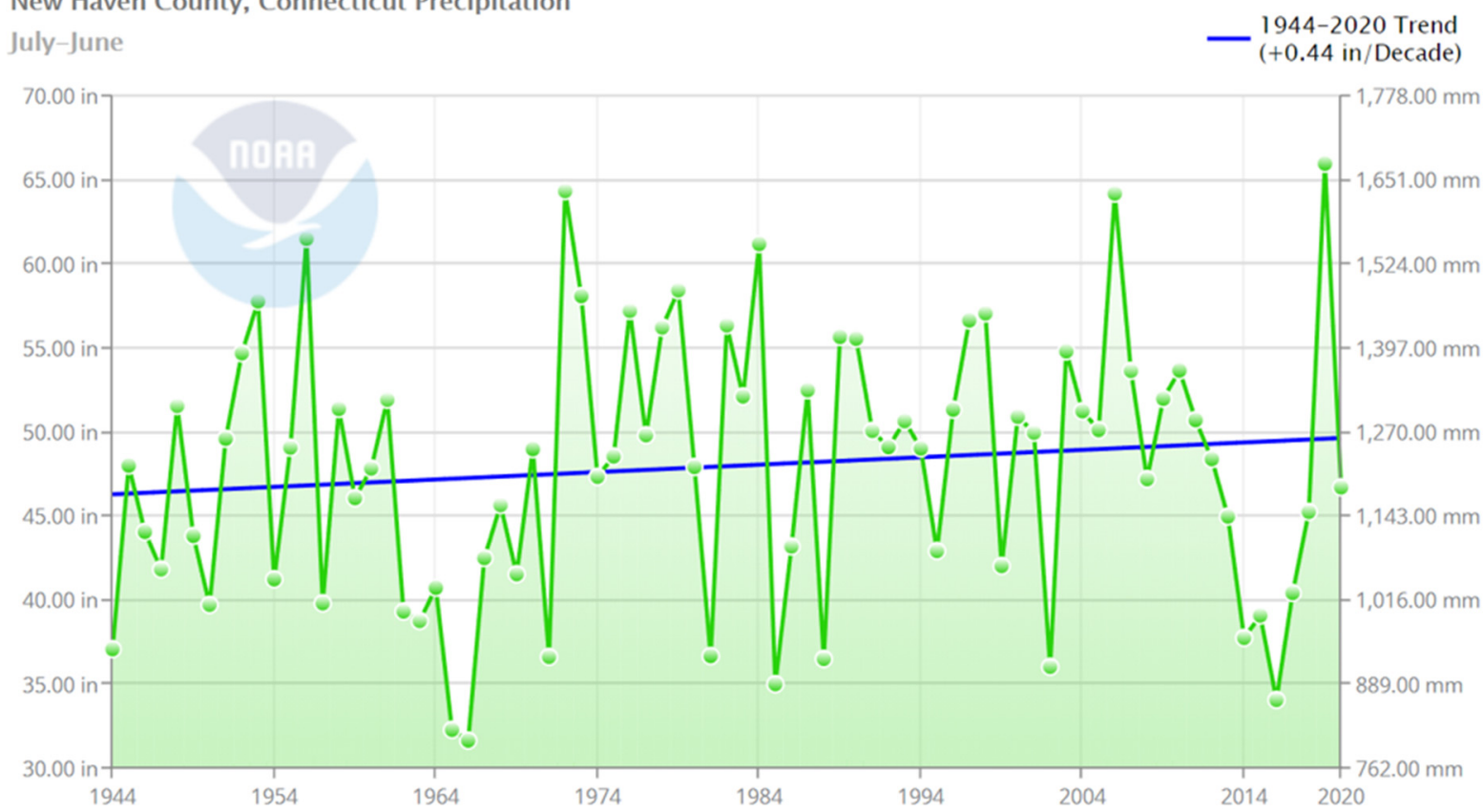

Figure 7. Average temperature (a) and precipitation (b) in New Haven County, Connecticut, from 1944 to 2020 (NOAA).

The concept of winners and losers in the face of globalization and climate change is widely accepted, with the characterization of the winners as exotic species and the losers as native. However, this is often not an accurate portrayal, as biotic homogenization also occurs without the invasion of alien species, and native biotic assemblages are often rearranged when subjected to anthropogenic disturbance [107]. All species that differed 
in abundance between the 1940s and the current survey, including L. sericata, P. regina, $L$. coeruleiviridis, L. illustris, C. vicina, and C. livida, are native to the region $[68,69]$ and should be considered as such given their length of time in the region and evidence in the current environment of life history traits being as the result of interspecific competition [108]. As no invasive necrophagous fly species such as Ch. rufifacies and L. cuprina have been recorded to date in New Haven, this is an example of a native biota that has been exposed to persistent disturbance and is experiencing biotic homogenization driven by the hyper-proliferation of native species rather than being replaced by alien species [107].

Urbanization can result in an increase in total insect abundance due to a higher abundance of generalist urbanophiles and the concentration of resources [109]. Arthropods in most urban systems are controlled through resource-based competition or bottom-up forces [110]. While the availability of domestic food waste and animal feces increases the availability of food, the poor nutritional value of such substances is often unable to sustain developing larvae, reducing survival, fecundity, and the size of adults [111,112]. While such an observation is anecdotal at this stage, L. sericata adult specimens in the current survey were noticeably smaller than specimens examined from other regions. Phormia regina, one of the world's most common species, may be an example of a species that has been lost from a region, with historical materials suggesting the species may have been present once, but it is now extinct in Britain and Sardinia [113].

Several differences should be noted between the trapping methodology used in the 1940s and the present day survey. Not all of the specimens trapped in the 1940s survey were identified; rather, 100 flies were randomly selected and identified from each trap. Fly numbers for the 1940s survey were also expressed in volume $\left(\mathrm{cm}^{3}\right)$, while in the current survey, all specimens were counted and identified. Given that not all of the specimens in the 1940s survey were identified, the difference in species diversity between the two surveys may be greater. The number of trapped flies was far greater in the 1940s, and some of this difference may be accounted for by the presence of a permanent source of horse manure and bi-weekly trappings rather than weekly. However, equally large numbers of flies were trapped weekly in a 1959-1960 New Haven study, where no horse manure was present, and a bait of similar size and type (chicken intestines) was used [80]. The number of flies entering a trap in the current survey never reached the abundance and diversity of the 1940s survey, despite baiting one of the present day traps with a decomposing pig head on a 25 degrees day in the early fall.

As noted, different type of fly traps were used in the 1940s and the current survey; however, they are of a similar type and size. The hanging Diptera cone trap [42] used in the present day study and the conical hoop flytrap $[1,43]$ used in the 1940s survey are of similar design, composed of an inverted screen cone inside a screen cylinder placed over a container holding bait. In both traps, flies enter the elevated base to access the bait and are trapped when flying or walking upwards through a small hole at the apex of the cone and into the cylinder. Both traps work on the principle that flies will fly upwards towards light after having been attracted beneath [43]. Both traps used had a base measuring approximately $30 \mathrm{~cm}$ wide and a cylinder approximately $30 \mathrm{~cm}$ high.

Different baits were used in the 1940s and the present-day survey: pooled mouse tissues and feces versus raw pork, while of comparable size. Past research has shown that the addition of manure to meat does increase the bait's attractiveness for some Calliphora and Chrysomya species, but not for Lucilia sericata [114]; the type of animal meat does not influence species richness or abundance [115], and L. sericata, L. coeruleiviridis and P. regina were equally attracted to beef liver and whole piglet carcasses [81]. However, the absence of manure from the present-day trap may explain why some species were not trapped, for example, species of the Scathophaga genus, which are primarily attracted to manure. The absence of manure from the present-day trap may account for the absence of four of the species listed in Table 4: Ch. splendida, D. picta, Toxomerus geminatus, and Scathophaga spp, while all other species have been shown to colonize carrion or frequent carrion baited traps $[42,81,116-120]$. 
The key difference between the trapping methodologies was trap placement. While the traps in both studies were placed between the hours of 9 a.m. and 4 p.m., the trap in the present day survey was hung approximately $1.5 \mathrm{~m}$ from the ground, while the trap in the 1940s survey would have been placed on the ground. Lucilia sericata trap numbers have been shown to be unaffected when comparing trap heights of 31, 61, and $91 \mathrm{~cm}$ [121]. A trap height of $0.5 \mathrm{~m}$, compared to above $1 \mathrm{~m}$, has been shown to affect numbers of $L$. cuprina, with a lower mean catch at $0.5 \mathrm{~m}$ [122]; however, such results suggest the low height of the 1940s trap may have limited trap numbers. Without data comparing the attractiveness of the two traps and baits used, it is difficult to rule out any influence these variables may have had on the number and diversity of flies trapped. However, given the similarity in methodology, it is believed that this influence would have been minimal compared to the long-term effects of changes in habitat and climatic variables.

Fly populations fluctuated markedly from year to year in the current survey and in the 1940 s survey. Lucilia. sericata, P. regina, and L. coeruleiviridis populations fluctuated markedly from year to year in the current survey, and L. sericata, P. regina, and L. illustris populations fluctuated from year to year in the 1940s survey. Volatile population dynamics are common in flies and other insects due to their ectothermic nature [123]. The development and oogenesis of flies is closely linked to temperature and precipitation, resulting in the synchronism of numerous generations and a quick increase in fly populations [124]. Such fluctuations make the interpretation of species-level demographic data difficult, as an annual decline of $1 \%$ to $2 \%$ is difficult to discern in the midst of such heterogeneity [30]. To determine if a decline or change is substantial and permanent, data should ideally be collected over several decades or include aggregate data at higher taxonomic levels [30]. The current survey period was limited to two years, and the comparative periods are separated by a wide gap in time rather than a continuous record. This makes comparative analysis less than ideal, but still valid. The results of this study show a simultaneous change in several Diptera families and are complemented by survey data collected in the same and nearby states. In addition, a population variation characteristic of calliphorids and other families trapped would have been captured in survey data given that both surveys were conducted over several weeks and over multiple years. Local-scale studies are necessary as they can highlight changes in populations that are often lost in multitaxon studies that combine insects from different regions with different ecological needs [30]. While the global decline of insects is evident, patterns of variation exist at the local scale, necessitating local surveys such as this to help identify local-scale drivers responsible for changes in population trends [28].

It was fortuitous in one sense that a survey of the local fly population in New Haven, Connecticut, was made in the 1940s due to questions regarding whether flies transmit polio after the virus was isolated from several fly species. Ten years later, in the early 1950s, the transmission of polio by flies was no longer viewed as important after fly abatement efforts demonstrated that flies were not a true host of the virus and any fly transmission was considered incidental [125-127]. However, fly surveys were repeated in New Haven in 1959-1960 and concluded that polio was readily found in flies during an urban epidemic. The presence of the virus in flies mirrored the level of clinical disease in the population, and flies were considered to be a possible source of epidemic variant strains [80,128].

Today, the role flies play in an epidemic is again being questioned with the current novel severe acute respiratory syndrome coronavirus 2 (SARS-CoV-2) pandemic. SARSCoV-2 was first detected in New Haven in March 2020, nine months after the current fly survey began. While the World Health Organization considers the flies' role in the transmission of the virus to again be incidental [129] research is starting to emerge demonstrating that flies are capable of transmitting SARS-CoV-2 and that infected flies are present in field samples from infected communities $[130,131]$. As the pandemic continues across the US and the world, an increase in fly surveys should be anticipated, providing the impetus to generate further comparative studies of domestic filth flies. 
Author Contributions: J.P.: conceptualization, methodology, formal analysis, writing-original draft, and writing-review and editing. P.A.M.: project administration, supervision, methodology, and writing-review and editing. I.R.D.: supervision, methodology, and writing-review and editing. R.C.O.: supervision, methodology, writing-review and editing, and resources. All authors have read and agreed to the published version of the manuscript.

Funding: This research was funded by an Australian Government Research Training Program Scholarship.

Institutional Review Board Statement: Not applicable.

Informed Consent Statement: Not applicable.

Data Availability Statement: No data availability.

Acknowledgments: The authors would like to thank members of the entomology group at the Yale Peabody Museum of Natural History for their valued opinions.

Conflicts of Interest: The authors declare no conflict of interest.

\section{References}

1. Power, M.E.; Melnick, J.L.; Bishop, M.B. A Study of the 1942 Fly Population of New Haven. Yale J. Biol. Med. 1943, 15, 693-705. [PubMed]

2. Power, M.E.; Melnick, J.L. A Three-year Survey of the Fly Population in New Haven During Epidemic and Non-epidemic Years for Poliomyelitis. Yale J. Biol. Med. 1945, 18, 55-69. [PubMed]

3. Paul, J.R.; Trask, J.D.; Bishop, M.B.; Melnick, J.L.; Casey, A.E. The detection of poliomyelitis virus in flies. Science 1941, 94, 395-396. [CrossRef] [PubMed]

4. Melnick, J.L.; Penner, L.R. The survival of poliomyelitis and Coxsackie viruses following their ingestion by flies. J. Exp. Med. 1952, 96, 255-271. [CrossRef]

5. Trask, J.D.; Paul, J.R.; Melnick, J.L.; Technical Assistance of John, T.R.; Marshall, B. The detetction of poliomyelitis virus in flies collected during epidemics of poliomyelitis: I. Methods, results, and types of flies involved. J. Exp. Med. 1943, 77, 531-544. [CrossRef] [PubMed]

6. Graczyk, T.K.; Knight, R.; Gilman, R.H.; Cranfield, M.R. The role of non-biting flies in the epidemiology of human infectious diseases. Microbes Infect. 2001, 3, 231-235. [CrossRef]

7. Khamesipour, F.; Lankarani, K.B.; Honarvar, B.; Kwenti, T.E. A systematic review of human pathogens carried by the housefly (Musca domestica L.). BMC Public Health 2018, 18, 1049. [CrossRef] [PubMed]

8. Greenberg, B. Flies and Disease-Ecology, Classification and Biotic Association; Princeton University Press: Princeton, NJ, USA, 1971.

9. da Cruz, L.; Dadour, I.R.; McAllister, I.L.; Jackson, A.; Isaacs, T. Seasonal variation in trachoma and bush flies in north-western Australian Aboriginal communities. Clin. Exp. Ophthalmol. 2002, 30, 80-83. [CrossRef]

10. Forsey, T.; Darougar, S. Transmission of chlamydiae by the housefly. Br. J. Ophthalmol. 1981, 65, 147-150. [CrossRef] [PubMed]

11. Stoffolano, J.G. Chapter Two-Fly foregut and transmission of microbes. In Advances in Insect Physiology; Jurenka, R., Ed.; Academic Press: London, UK, 2019; Volume 57, pp. 27-95.

12. Greenberg, B. Forensic Entomology: Case Studies. Bull. Entomol. Soc. Am. 1985, 31, 25-28. [CrossRef]

13. Catts, E.P.; Goff, M.L. Forensic Entomology in Criminal Investigations. Annu. Rev. Entomol. 1992, 37, 253-272. [CrossRef] [PubMed]

14. Amendt, J.; Richards, C.S.; Campobasso, C.P.; Zehner, R.; Hall, M.J. Forensic entomology: Applications and limitations. Forensic Sci. Med. Pathol. 2011, 7, 379-392. [CrossRef]

15. Rader, R.; Cunningham, S.A.; Howlett, B.G.; Inouye, D.W. Non-Bee Insects as Visitors and Pollinators of Crops: Biology, Ecology, and Management. Annu. Rev. Entomol. 2020, 65, 391-407. [CrossRef] [PubMed]

16. Cook, D.; Voss, S.; Finch, J.; Rader, R.; Cook, J.; Spurr, C. The Role of Flies as Pollinators of Horticultural Crops: An Australian Case Study with Worldwide Relevance. Insects 2020, 11, 341. [CrossRef] [PubMed]

17. Cabrini, I.; Grella, M.D.; Andrade, C.F.S.; Thyssen, P.J. Richness and composition of Calliphoridae in an Atlantic Forest fragment: Implication for the use of dipteran species as bioindicators. Biodivers. Conserv. 2013, 22, 2635-2643. [CrossRef]

18. Gaston, K.; Fuller, R. Commonness, population depletion and conservation biology. Trends Ecol. Evol. 2008, 23, 14-19. [CrossRef] [PubMed]

19. Gaston, K.J. Valuing Common Species. Science 2010, 327, 154-155. [CrossRef]

20. Conrad, K.F.; Warren, M.S.; Fox, R.; Parsons, M.S.; Woiwod, I.P. Rapid declines of common, widespread British moths provide evidence of an insect biodiversity crisis. Biol. Conserv. 2006, 132, 279-291. [CrossRef]

21. Seress, G.; Bókony, V.; Pipoly, I.; Szép, T.; Nagy, K.; Liker, A. Urbanization, nestling growth and reproductive success in a moderately declining house sparrow population. J. Avian Biol. 2012, 43, 403-414. [CrossRef]

22. Gaston, K.J.; Fuller, R.A. Biodiversity and extinction:losing the common and the widespread. Prog. Phys. Geogr. Earth Environ. 2007, 31, 213-225. [CrossRef] 
23. Dufrene, M.; Legendre, P. Species Assemblages and Indicator Species: The Need for a Flexible Asymmetrical Approach. Ecol. Monogr. 1997, 67, 345-366. [CrossRef]

24. Hilty, J.; Merenlender, A. Faunal indicator taxa selection for monitoring ecosystem health—Lessons from the US Forest Service. Biol. Conserv. 2000, 92, 185-197. [CrossRef]

25. De Sousa, J.R.P.; Esposito, M.C.; Carvalho Filho, F.d.S.; Juen, L. The potential uses of sarcosaprophagous flesh flies and blowflies for the evaluation of the regeneration and conservation of forest clearings: A case study in the Amazon forest. J. Insect Sci. 2014, 14, 215. [CrossRef] [PubMed]

26. Goulson, D.; Derwent, L.C.; Hanley, M.E.; Dunn, D.W.; Abolins, S.R. Predicting calyptrate fly populations from the weather, and probable consequences of climate change. J. Appl. Ecol. 2005, 42, 795-804. [CrossRef]

27. Sánchez-Bayo, F.; Wyckhuys, K.A.G. Worldwide decline of the entomofauna: A review of its drivers. Biol. Conserv. 2019, 232, 8-27. [CrossRef]

28. van Klink, R.; Bowler, D.E.; Gongalsky, K.B.; Swengel, A.B.; Gentile, A.; Chase, J.M. Meta-analysis reveals declines in terrestrial but increases in freshwater insect abundances. Science 2020, 368, 417-420. [CrossRef]

29. Sánchez-Bayo, F.; Wyckhuys, K.A.G. Further evidence for a global decline of the entomofauna. Austral Entomol. 2021, 60, 9-26. [CrossRef]

30. Wagner, D.L.; Grames, E.M.; Forister, M.L.; Berenbaum, M.R.; Stopak, D. Insect decline in the Anthropocene: Death by a thousand cuts. Proc. Natl. Acad. Sci. USA 2021, 118, e2023989118. [CrossRef]

31. Wagner, D.L.; Van Driesche, R.G. Threats posed to rare or endangered insects by invasions of nonnative species. Annu. Rev. Entomol. 2010, 55, 547-568. [CrossRef]

32. Laurence, B.R. Old world blowflies in the new world. Parasitol. Today 1986, 2, 77-79. [CrossRef]

33. Meyerson, L.A.; Mooney, H.A. Invasive alien species in an era of globalization. Front. Ecol. Environ. 2007, 5, 199-208. [CrossRef]

34. Owings, C.G.; Picard, C.J. New Distribution Record for Lucilia cuprina (Diptera: Calliphoridae) in Indiana, United States. J. Insect Sci. 2018, 18, 8. [CrossRef] [PubMed]

35. Byrd, J.H.; Butler, J.F. Effects of temperature on Chrysomya rufifacies (Diptera:Calliphoridae) development. J. Med. Entomol. 1997, 34, 353-358. [CrossRef] [PubMed]

36. Rosati, J.; Vanlaerhoven, S. New record of Chrysomya rufifacies (Diptera: Calliphoridae) in Canada: Predicted range expansion and potential effects on native species. Can. Entomol. 2007, 139, 670-677. [CrossRef]

37. Wagner, D.L. Moth decline in the northeastern United States. News Lepid. Soc. 2012, 54, 52-56.

38. Petruff, T.A.; McMillan, J.R.; Shepard, J.J.; Andreadis, T.G.; Armstrong, P.M. Increased mosquito abundance and species richness in Connecticut, United States 2001-2019. Sci. Rep. 2020, 10, 19287. [CrossRef] [PubMed]

39. Von Holle, B.; Motzkin, G. Historical land use and environmental determinants of nonnative plant distribution in coastal southern New England. Biol. Conserv. 2007, 136, 33-43. [CrossRef]

40. Amendt, J. Insect Decline-A Forensic Issue? Insects 2021, 12, 324. [CrossRef]

41. Gillespie, M.A.K.; Alfredsson, M.; Barrio, I.C.; Bowden, J.J.; Convey, P.; Culler, L.E.; Coulson, S.J.; Krogh, P.H.; Koltz, A.M.; Koponen, S.; et al. Status and trends of terrestrial arthropod abundance and diversity in the North Atlantic region of the Arctic. Ambio 2020, 49, 718-731. [CrossRef] [PubMed]

42. Pinto, J.; Magni, P.; O’Brien, R.C.; Dadour, I. Forensically relevant blow flies (Diptera: Calliphoridae) of Central Connecticut, USA. Forensic Sci. Int. 2021, 327, 110940. [CrossRef]

43. Bishopp, F.C. Fly Traps and Their Operation; USDA Farmers' Bulletin No. 734; U.S. Department of Agriculture: Washington, DC, USA, 1921.

44. Whitworth, T. Keys to the Genera and Species of Blowflies (Diptera: Calliphoridae) of America, North of Mexico (Updates and Edits as of Spring 2017). Proc. Entomol. Soc. Wash. 2006, 108, 689-725.

45. Dodge, H.R. Diptera: Pictorial Key to Principal Families of Public Health Importance; U.S. Department of Health: Atlanta, GA, USA, 1953.

46. ESRI. ArcGIS Desktop: Release 10; Environmental Systems Research Institute: Redlands, CA, USA, 2011.

47. UCONN. MAGIC:1954 Land Use Land Cover; UCONN: Storrs, CT, USA, 1954.

48. Rae, D.W. City: Urbanism and Its End; Yale University Press: London, UK, 2003.

49. EPA: What Climate Change Means for Connecticut. Available online: https://19january2017snapshot.epa.gov/sites/production/ files / 2016-09/documents / climate-change-ct.pdf (accessed on 24 May 2021).

50. UCONN Center for Land Use Education \& Research, Connecticut and Long Island Sound Land Cover and Change-1985 to 2015. Available online: http:/ / clear.uconn.edu/projects/landscape/about/layers.htm\#top (accessed on 24 May 2021).

51. Maples, S. Urban Tree Canopy Neighborhood Metrics for New Haven, CT. Available online: https://uri.yale.edu/maps/urbantree-canopy-metrics (accessed on 8 June 2021).

52. U.S. Geological Survey. New Haven Quadrangle Topographic Map 1:62,500, 01/01/1892; U.S. Geological Survey: Reston, VA, USA, 1892.

53. U.S. Geological Survey. New Haven Quadrangle Topographic Map 1:125,000, 01/01/1942; U.S. Geological Survey: Reston, VA, USA, 1942.

54. U.S. Geological Survey. New Haven Quadrangle Topographic Map 1:24,000; U.S. Geological Survey: Reston, VA, USA, 1954. 
55. Grassberger, M.; Friedrich, E.; Reiter, C. The blowfly Chrysomya albiceps (Wiedemann) (Diptera: Calliphoridae) as a new forensic indicator in Central Europe. Int. J. Leg. Med. 2003, 117, 75-81. [CrossRef] [PubMed]

56. Hall, D.G. The Blowflies of North. America; Thomas Say Foundation: Baltimore, MD, USA, 1948.

57. Rueda, L.; Ortega, L.; Segura Guerrero, N.; Acero, V.; Bello, F. Lucilia sericata strain from Colombia: Experimental Colonization, Life Tables and Evaluation of Two Artifcial Diets of the Blowfy Lucilia sericata (Meigen) (Diptera: Calliphoridae), Bogotá, Colombia Strain. Biol. Res. 2010, 43, 197-203. [CrossRef] [PubMed]

58. Zumpt, F. Myiasis in Man and Animals in the Old World; A Textbook for Physicians, Veterinarians and Zoologists; Butterworth: London, UK, 1965.

59. Nuorteva, P. Synanthropy of blowflies (Dipt., Calliphoridae) in Finland. Ann. Entomol. Fenn. 1963, $29,1-49$.

60. Brundage, A.; Bros, S.; Honda, J.Y. Seasonal and habitat abundance and distribution of some forensically important blow flies (Diptera: Calliphoridae) in Central California. Forensic Sci. Int. 2011, 212, 115-120. [CrossRef] [PubMed]

61. Schnack, J.; Mariluis, J.; Spinelli, G.; Muzón, J. Ecological aspects on urban blowflies in midwest Argentinean Patagonia (Diptera: Calliphoridae). Rev. Soc. Entomológica Argent. 1998, 57, 127-130.

62. Mariluis, J.; Schnack, J.; Mulieri, P.; Patitucci, L. Calliphoridae (Diptera) from wild, suburban, and urban sites at three Southeast Patagonian localities: Calliphoridae (Diptera) de ambientes no habitados, suburbanos y urbanos en tres localidades del sudeste patagónico. Rev. Soc. Entomológica Argent. 2008, 67, 107-114.

63. Stevens, J.; Wall, R. Species, sub-species and hybrid populations of the blowflies Lucilia cuprina and Lucilia sericata (Diptera:Calliphoridae). Proc. Biol. Sci. 1996, 263, 1335-1341. [CrossRef]

64. Tomberlin, J.K.; Adler, P.H. Seasonal colonization and decomposition of rat carrion in water and on land in an open field in South Carolina. J. Med. Entomol. 1998, 35, 704-709. [CrossRef] [PubMed]

65. Singh, D.; Greenberg, B. Survival after submergence in the pupae of five species of blow flies (Diptera: Calliphoridae). J. Med. Entomol. 1994, 31, 757-759. [CrossRef] [PubMed]

66. Magni, P.A.; Senigaglia, V.; Robinson, S.C.; Dadour, I.R. The effect of submersion in different types of water on the survival and eclosion of blow-fly intra-puparial forms (Diptera: Calliphoridae). Forensic Sci. Int. 2021, 319, 110663. [CrossRef]

67. Williams, R.W. A Study of the Filth Flies in New York City-1953. J. Econ. Entomol. 1953, 47, 556-563. [CrossRef]

68. Williams, K.A.; Lamb, J.; Villet, M.H. Phylogenetic radiation of the greenbottle flies (Diptera, Calliphoridae, Luciliinae). Zookeys 2016, 568, 59-86. [CrossRef]

69. Tantawi, T.I.; Whitworth, T.L.; Sinclair, B.J. Revision of the Nearctic Calliphora Robineau-Desvoidy (Diptera: Calliphoridae). Zootaxa 2017, 4226, 301-347. [CrossRef] [PubMed]

70. Marshall, S.A.; Whitworth, T.; Roscoe, L. Blow flies (Diptera; Calliphoridae) of eastern Canada with a key to Calliphoridae subfamilies and genera of eastern North America, and a key to the eastern Canadian species of Calliphorinae, Luciliinae and Chrysomyiinae. Can. J. Arthropod Identif. 2011, 11, 1-93. [CrossRef]

71. Tabor, K.L.; Brewster, C.C.; Fell, R.D. Analysis of the Successional Patterns of Insects on Carrion in Southwest Virginia. J. Med. Entomol. 2004, 41, 785-795. [CrossRef] [PubMed]

72. Gruner, S.V.; Slone, D.H.; Capinera, J.L. Forensically important calliphoridae (diptera) associated with pig carrion in rural north-central Florida. J. Med. Entomol. 2007, 44, 509-515. [CrossRef] [PubMed]

73. Weidner, L.; Tomberlin, J.; Hamilton, G. Development of Lucilia coeruleiviridis (Diptera: Calliphoridae) in New Jersey, USA. Fla. Entomol. 2014, 97, 849-851. [CrossRef]

74. Bugajski, K.N.; Tolle, C. Effect of wáter on blow fly (Diptera: Calliphoridae) colonization of pigs in Northwest Indiana. Proc. Ind. Acad. Sci. 2014, 123, 67-71.

75. Jordaens, K.; Sonet, G.; Braet, Y.; De Meyer, M.; Backeljau, T.; Goovaerts, F.; Bourguignon, L.; Desmyter, S. DNA barcoding and the differentiation between North American and West European Phormia regina (Diptera, Calliphoridae, Chrysomyinae). Zookeys 2013, 365, 149-174. [CrossRef] [PubMed]

76. Byrd, J.H.; Allen, J.C. The development of the black blow fly, Phormia regina (Meigen). Forensic Sci. Int. 2001, 120, 79-88. [CrossRef]

77. Savage, E.P.; Schoof, H.F. The Species Composition of Fly Populations at Several Types of Problem Sites in Urban Areas. Ann. Entomol. Soc. Am. 1955, 48, 251-257. [CrossRef]

78. Denno, R.F.; Cothran, W.R. Competitive Interactions and Ecological Strategies of Sarcophagid and Calliphorid Flies Inhabiting Rabbit Carrion. Ann. Entomol. Soc. Am. 1976, 69, 109-113. [CrossRef]

79. Hans, K.R.; Vanlaerhoven, S.L. Impact of Comingled Heterospecific Assemblages on Developmentally Based Estimates of the PostMortem Interval-A Study with Lucilia sericata (Meigen), Phormia regina (Meigen) and Calliphora vicina Robineau-Desvoidy (Diptera: Calliphoridae). Insects 2021, 12, 280. [CrossRef] [PubMed]

80. Downey, T.W. Polioviruses and Flies: Studies on the Epidemiology of Enteroviruses in an Urban Area. Yale J. Biol. Med. 1963, 35, 341-352.

81. Weidner, L.M.; Gemmellaro, M.D.; Tomberlin, J.K.; Hamilton, G.C. Evaluation of bait traps as a means to predict initial blow fly (Diptera: Calliphoridae) communities associated with decomposing swine remains in New Jersey, USA. Forensic Sci. Int. 2017, 278, 95-100. [CrossRef] [PubMed]

82. LeBlanc, K.; Boudreau, D.R.; Moreau, G. Small Bait Traps May Not Accurately Reflect the Composition of Necrophagous Diptera Associated to Remains. Insects 2021, 12, 261. [CrossRef] [PubMed] 
83. PrinkkilÁ, M.-L.; Hanski, I. Complex competitive interactions in four species of Lucilia blowflies. Ecol. Entomol. 1995, 20, 261-272. [CrossRef]

84. Stevens, J.; Wall, R. The evolution of ectoparasitism in the genus Lucilia (Diptera:Calliphoridae). Int. J. Parasitol. 1997, 27, 51-59. [CrossRef]

85. Nuorteva, P. Differences in the ecology of Lucilia ceasar (L.) and Lucilia illustris (Meig.) (Diptera, Calliphoridae) in Finland. Wiadomości. Parazytol. 1964, 10, 583-587.

86. Hwang, C.; Turner, B.D. Spatial and temporal variability of necrophagous Diptera from urban to rural areas. Med. Vet. Entomol. 2005, 19, 379-391. [CrossRef] [PubMed]

87. Judd, W.W. Results of a Survey of Calyptrate Flies of Medical Importance Conducted at London, Ontario During 1953. Am. Midl. Nat. 1956, 56, 388-405. [CrossRef]

88. Maldonado, M.; Centeno, N. Quantifying the Potential Pathogens Transmission of the Blowflies (Diptera: Calliphoridae). Memórias Do Inst. Oswaldo Cruz. 2003, 98, 213-216. [CrossRef] [PubMed]

89. Arnold, C.L.; Gibbons, C.J. Impervious Surface Coverage: The Emergence of a Key Environmental Indicator. J. Am. Plan. Assoc. 1996, 62, 243-258. [CrossRef]

90. Geslin, B.; Le Féon, V.; Folschweiller, M.; Flacher, F.; Carmignac, D.; Motard, E.; Perret, S.; Dajoz, I. The proportion of impervious surfaces at the landscape scale structures wild bee assemblages in a densely populated region. Ecol. Evol. 2016, 6, 6599-6615. [CrossRef]

91. Lagucki, E.; Burdine, J.D.; McCluney, K.E. Urbanization alters communities of flying arthropods in parks and gardens of a medium-sized city. PeerJ 2017, 5, e3620. [CrossRef]

92. Rozsa, R. Human impacts on tidal wetlands: History and regulations. In Tidal Marshes of Long Island Sound: Ecology, History and Restoration; The Connecticut Arboretum Press: New London, CT, USA, 1995; Volume 34, pp. 42-50.

93. Climate at a Glance: County Time Series. Available online: https:/ / www.ncdc.noaa.gov/cag/ (accessed on 3 June 2021).

94. Bozzi, L. Climate Change and Health in Connecticut: 2020 Report; Yale Center on Climate Change and Health: New Haven, CT, USA, 2020.

95. Vogt, W.G.; Woodburn, T.L.; Morton, R.; Ellem, B.A. The analysis and standardisation of trap catches of Lucilia cuprina (Wiedemann) (Diptera: Calliphoridae). Bull. Entomol. Res. 2009, 73, 609-617. [CrossRef]

96. Patitucci, L.D.; Mulieri, P.R.; Schnack, J.A.; Mariluis, J.C. Species composition and heterogeneity of blowflies assemblages (Diptera: Calliphoridae) in urban-rural gradients at regional scale in Argentinean Patagonia. Stud. Neotrop. Fauna Environ. 2011, 46, 49-58. [CrossRef]

97. McGlynn, T.P.; Meineke, E.K.; Bahlai, C.A.; Li, E.; Hartop, E.A.; Adams, B.J.; Brown, B.V. Temperature accounts for the biodiversity of a hyperdiverse group of insects in urban Los Angeles. Proc. Biol. Sci. 2019, 286, 20191818. [CrossRef] [PubMed]

98. McKinney, M. McKinney, M.L. Urbanization as a major cause of biotic homogenization. Biological Conservation. Biol. Conserv. 2006, 127, 247-260. [CrossRef]

99. Rocha, E.A.; Fellowes, M.D.E. Urbanisation alters ecological interactions: Ant mutualists increase and specialist insect predators decrease on an urban gradient. Sci. Rep. 2020, 10, 6406. [CrossRef]

100. Grimm, N.B.; Faeth, S.H.; Golubiewski, N.E.; Redman, C.L.; Wu, J.; Bai, X.; Briggs, J.M. Global change and the ecology of cities. Science 2008, 319, 756-760. [CrossRef] [PubMed]

101. Meillère, A.; Brischoux, F.; Parenteau, C.; Angelier, F. Influence of Urbanization on Body Size, Condition, and Physiology in an Urban Exploiter: A Multi-Component Approach. PLoS ONE 2015, 10, e0135685. [CrossRef] [PubMed]

102. Ullyett, G.C.; Thompson, W.R. Competition for food and allied phenomena in sheep-blowfly populations. Philos. Trans. R. Soc. Lond. Ser. B Biol. Sci. 1950, 234, 77-174. [CrossRef]

103. Carmo, R. How do invasive species affect native species? Experimental evidence from a carrion blowfly (Diptera: Calliphoridae) system. Ecol. Entomol. 2018, 43, 483-493. [CrossRef]

104. Esposito, M.; Sousa, J.R.P.D.; Carvalho-Filho, F.D.S. Diversidade de Calliphoridae (Insecta: Diptera) na base de extração petrolífera da Bacia do Rio Urucu, na Amazônia brasileira. Acta Amazon. 2010, 40, 579-584. [CrossRef]

105. Centeno, N.; Almorza, D.; Arnillas, C. Diversity of Calliphoridae (Insecta: Diptera) in Hudson, Argentina. Neotrop. Entomol. Neotrop. Entomol. 2004, 33, 387-390. [CrossRef]

106. Langer, S.V.; Kyle, C.J.; Illes, M.; Larkin, S.; Beresford, D.V. Urban and Rural Spatial Delineations in Blow Fly Species (Diptera: Calliphoridae) Across Canada: Implications for Forensic Entomology. J. Med. Entomol. 2019, 56, 927-935. [CrossRef] [PubMed]

107. Tabarelli, M.; Peres, C.A.; Melo, F.P.L. The 'few winners and many losers' paradigm revisited: Emerging prospects for tropical forest biodiversity. Biol. Conserv. 2012, 155, 136-140. [CrossRef]

108. Carthey, A.J.; Banks, P.B. When does an alien become a native species? A vulnerable native mammal recognizes and responds to its long-term alien predator. PLoS ONE 2012, 7, e31804. [CrossRef] [PubMed]

109. Adams, B.J.; Li, E.; Bahlai, C.A.; Meineke, E.K.; McGlynn, T.P.; Brown, B.V. Local- and landscape-scale variables shape insect diversity in an urban biodiversity hot spot. Ecol. Appl. 2020, 30, e2089. [CrossRef] [PubMed]

110. Faeth, S.H.; Bang, C.; Saari, S. Urban biodiversity: Patterns and mechanisms. Ann. N. Y. Acad. Sci. 2011, 1223, 69-81. [CrossRef] [PubMed]

111. Castelli, L.E.; Gleiser, R.M.; Battán-Horenstein, M. Role of saprophagous fly biodiversity in ecological processes and urban ecosystem services. Ecol. Entomol. 2020, 45, 718-726. [CrossRef] 
112. Ribeiro, C.; Zuben, C. Nutritional ecology of blowflies (Diptera, Calliphoridae): Estimates of critical larval weight for pupation on two different diets. Rev. Bras. Entomol. 2009, 54, 661-664. [CrossRef]

113. Sivell, O. Phormia regina (Meigen) (Diptera, Calliphoridae) in Britain. Dipterists Digest 2018, 25, $113-118$.

114. Harvey, M.; Gasz, N.; Woolley, Z.; Roberts, L.; Raven, N.; Colbert, A.; Law, K.; Marshall, P.; Voss, S. Dipteran Attraction to a Variety of Baits: Implications for Trapping Studies as a Tool for Establishing Seasonal Presence of Significant Species. J. Med. Entomol. 2019, 56, 1283-1289. [CrossRef] [PubMed]

115. Vasconcelos, S.D.; Barbosa, T.M.; Oliveira, T.P.B. Diversity of forensically-important dipteran species in different environments in northeastern Brazil, with notes on the attractiveness of animal baits. Fla. Entomol. 2015, 98, 770-775. [CrossRef]

116. Weidner, L.M.; Jennings, D.E.; Tomberlin, J.K.; Hamilton, G.C. Seasonal and Geographic Variation in Biodiversity of Forensically Important Blow Flies (Diptera: Calliphoridae) in New Jersey, USA. J. Med. Entomol. 2015, 52, 937-946. [CrossRef]

117. Pedraza-Lara, C.; Garduño-Sánchez, M.A.; Téllez-García, I.; Rodríguez-González, S.; Nuple-Juárez, E.; Guardado-Estrada, M. Species Delimitation of Scavenger Flies in the Valley of Mexico. J. Med. Entomol. 2021, tjab094. [CrossRef] [PubMed]

118. Pérez, A.E. The Development of an Insect Succession Model Suitable for Time-Since-Death Statistics; Graduate Theses, Dissertations, and Problem Reports; West Virginia University: Morgantown, WV, USA, 2014; Volume 7339.

119. Payne, J.A.; Crossley, D.A., Jr. Animal Species Associated with Pig Carrion; No. ORNL-TM-1432; Oak Ridge National Laboratory: Oak Ridge, TN, USA, 1966.

120. Magni, P.A.; Pérez-Bañón, C.; Borrini, M.; Dadour, I.R. Syritta pipiens (Diptera: Syrphidae), a new species associated with human cadavers. Forensic Sci. Int. 2013, 231, e19-e23. [CrossRef] [PubMed]

121. Bilaniuk, V.; Beresford, D.V. Sampling adult blow flies (Diptera: Calliphoridae) at pig carcasses with sticky traps: Effects of trap colour, height, and inclination. Can. Soc. Forensic Sci. J. 2010, 43, 181-190. [CrossRef]

122. Vogt, W.; Gerwen, A.; Morton, R. Influence of Trap Height on Catches of Lucilia cuprina (Wiedemann) (Diptera: Calliphoridae) in Wind-Oriented Fly Traps. Aust. J. Entomol. 2007, 34, 225-227. [CrossRef]

123. Harrison, J.G.; Shapiro, A.M.; Espeset, A.E.; Nice, C.C.; Jahner, J.P.; Forister, M.L. Species with more volatile population dynamics are differentially impacted by weather. Biol. Lett. 2015, 11, 20140792. [CrossRef] [PubMed]

124. Luz, R.T.; Azevedo, W.T.A.; Silva, A.S.; Lessa, C.S.S.; Maia, V.C.; Aguiar, V.M. Population Fluctuation, Influence of Abiotic Factors and the Height of Traps on the Abundance and Richness of Calliphoridae and Mesembrinellidae. J. Med. Entomol. 2020, 57, 1748-1757. [CrossRef]

125. Cirillo, V.J. "I Am the Baby Killer!" House Flies and the Spread of Polio. Am. Entomol. 2016, 62, 83-85. [CrossRef]

126. Dowdle, W.R.; Birmingham, M.E. The biologic principles of poliovirus eradication. J. Infect. Dis. 1997, 175 (Suppl. 1), S286-S292. [CrossRef]

127. Paffenbarger, R.S.J.; Watt, J. Poliomyelitis in Hidalgo County, Texas, 1948 epidemiologic observations. Am. J. Epidemiol. 1953, 58, 269-287. [CrossRef] [PubMed]

128. Gudnadóttir, M.T.G. Studies of the fate of type 1 polioviruses in flies. J. Exp. Med. 1961, 113, 159-176. [CrossRef] [PubMed]

129. WHO. Available online: https://www.who.int/emergencies/diseases/novel-coronavirus-2019/advice-for-public/myth-busters (accessed on 21 June 2021).

130. Balaraman, V.; Drolet, B.S.; Mitzel, D.N.; Wilson, W.C.; Owens, J.; Gaudreault, N.N.; Meekins, D.A.; Bold, D.; Trujillo, J.D.; Noronha, L.E.; et al. Mechanical transmission of SARS-CoV-2 by house flies. Parasites Vectors 2021, 14, 214. [CrossRef] [PubMed]

131. Soltani, A.; Jamalidoust, M.; Hosseinpour, A.; Vahedi, M.; Ashraf, H.; Yousefinejad, S. First molecular-based detection of SARS-CoV-2 virus in the field-collected houseflies. Sci. Rep. 2021, 11, 13884. [CrossRef] [PubMed] 